\title{
Hydraulic and geochemical impact of occasional saltwater intrusions through a submarine spring in a karst and thermal aquifer (Balaruc peninsula near Montpellier, France)
}

\author{
Marie-Amélie Pétré ${ }^{1, a}$, Bernard Ladouche ${ }^{2}$, Jean-Luc Seidel ${ }^{1}$, Romain Hemelsdaël ${ }^{3}$, Véronique de Montety ${ }^{1}$, \\ Christelle Batiot-Guilhe ${ }^{1}$, and Claudine Lamotte $^{2}$ \\ ${ }^{1}$ HydroSciences Montpellier, Montpellier University, CNRS, IRD, Montpellier, France \\ ${ }^{2}$ BRGM, Montpellier University, Montpellier, France \\ ${ }^{3}$ Geosciences Montpellier, Montpellier University, CNRS, Montpellier, France \\ anow at: North Carolina State University, Marine, Earth, and Atmospheric Sciences Department, \\ Raleigh, NC 27695, United States
}

Correspondence: Marie-Amélie Pétré (marieamelie.petre@gmail.com)

Received: 15 June 2020 - Discussion started: 9 July 2020

Revised: 26 September 2020 - Accepted: 13 October 2020 - Published: 27 November 2020

\begin{abstract}
Submarine springs are a common discharge feature of the karst aquifers along the Mediterranean coast. In some instances, occasional and localized saltwater intrusions can occur through the submarine spring and negatively impact the quality of the groundwater resource. The hydraulic and geochemical behaviour of a submarine spring discharging into the Thau Lagoon just offshore of the Balaruc peninsula near Montpellier, France, has been characterized to determine the impacts of such phenomena to better understand the dynamics of a regional karst aquifer and improve its groundwater management. This work is based on both historical and new hydrogeological and geochemical data, illustrating six occasional saltwater intrusion events (from 1967 to 2014) in the Thau Lagoon area (southern France).

Hydraulic perturbation of the aquifer is propagated instantly within the Balaruc-les-Bains peninsula and reaches a distance of about $5 \mathrm{~km}$ upgradient within $9 \mathrm{~d}$. Comparison of hydraulic heads during seawater intrusion events in 2010 and 2014 indicates an aggravation of the phenomenon with an increase in hydraulic head variations.

In contrast, isotopic tracers $\left({ }^{87} \mathrm{Sr} /{ }^{86} \mathrm{Sr}, \mathrm{D} / \mathrm{H},{ }^{18} \mathrm{O} /{ }^{16} \mathrm{O}\right)$ and rare earth elements (REEs) demonstrate that the geochemical impact of these inversac events is only observed at the local scale but is still perceptible several years after the event. For example, some of the thermal wells had not recovered their initial geochemical state 20 and 40 months after the last two
\end{abstract}

inversac events (2010 and 2014, respectively), suggesting a geochemical legacy of this phenomenon within the complex karst system. By contrast, an adjacent deep karst compartment located south of the study area is not affected by the saltwater intrusion and is characterized by distinctly different hydrodynamic behaviour.

Overall, this work on occasional and localized saltwater intrusions constitutes a key step in understanding the dynamics of this complex karstic and thermal aquifer and will support the management of the groundwater resource.

\section{Introduction}

Submarine springs are common discharge features of karst systems along the Mediterranean coast (Bakalowicz, 2014; Fleury, 2005; Fleury et al., 2007; Stieglitz et al., 2013). Water from these springs can support economic development or be exploited for drinking water supply.

In certain instances, especially during periods of low discharge, flow can reverse and instead intrude into the upgradient karst aquifer, causing an adverse impact on the quality of the groundwater resource and the economic activities that depend on it (Arfib and Gilli, 2010; Drogue and Bidaux, 1986). This phenomenon, termed "inversac" in French (Gèse, 1987; Pinault et al., 2004), was previously 
described by Albéric (2004) and Joigneaux et al. (2011) in a related context of river backflooding into karst springs. However, occasional saltwater intrusion through a submarine spring is a largely understudied phenomenon.

The factors responsible for initiating and terminating inversac events in coastal areas are not particularly well understood, and the recovery of carbonate aquifers after a seawater intrusion is poorly described (Han et al., 2015). However, it is necessary to understand the mechanisms controlling this phenomenon as well as the long-term impact of occasional and localized saltwater intrusions to appropriately manage the groundwater resources of such karst systems.

In this context, a hydraulic and geochemical study was undertaken to characterize the occasional and localized saltwater intrusions into the karst aquifer of the Thau basin. More specifically, our study addressed the following questions: (i) what are the hydraulic and geochemical conditions in the karstic aquifer during and after an inversac event? (ii) What are the triggering factors contributing to the occurrence of the inversac event? (iii) To what extent is the aquifer system able to recover from an inversac event and get back to its original geochemical state? (iv) What are the implications in terms of groundwater resource management?

The Thau hydrosystem in the Balaruc-les-Bains area is an example of a karst and thermal aquifer affected by occasional saltwater intrusions through a submarine spring. This complex hydrologic system has been described by Aquilina et al. (1997, 2002, 2003), Doerfliger et al. (2001), and Ladouche et al. (2001). However, the causes and extent of the impact of the saltwater intrusions here remain poorly understood. The karst and thermal water resources across the Thau hydrosystem are exploited both for drinking water supply and spa activities. Balaruc-les-Bains (Fig. 1) is the largest spa in France, with 55000 visitors annually. In the past, water from the Vise submarine spring was diverted to the seashore and used for aquaculture activities. Additionally, the Thau Lagoon supports an extensive shellfish aquaculture and fishery. Thus, the economic stakes are high in this area and water use conflict has the potential to arise between stakeholders during dry conditions as a consequence of an increase in water demand and the occurrence of occasional saltwater intrusions (Chu et al., 2014; La Jeunesse et al., 2015). Indeed, the karst system has been affected by six inversac events through the Vise submarine spring over the past 50 years (Table 1), five of which $(1967,1983,2008,2010$, and 2014) have been documented and described (Ladouche et al., 2011, 2019; Ladouche and Lamotte, 2015). Human activities, such as bauxite mining upstream from the Vise spring and intervention on the spring itself, are thought to have contributed to the saltwater intrusions over the 1967-1993 period by drawing down the hydraulic head of the karst system. Historically, these inversac events produced an increase in the water level and electrical conductivity at the observation points (thermal well and spring) in the Balaruc peninsula. A better understanding of this phenomenon is for local use purposes but is also of strategic importance for water managers of the Issanka karst spring, a major drinking water supplier in the area.

The last two inversac events in 2010 and 2014 lasted 7 and 5 months, respectively. The 2014 inversac event led to the permanent abandonment of the Cauvy spring, which provided drinking water to a local population of 30000 .

Previous research in the study area focused primarily on the hydrochemistry and failed to consider the hydraulic impact of the inversac events. To fully describe this phenomenon, the present study combined hydrogeological data and a multi-tracer approach for several inversac events. A larger set of geochemical tracers was used to better define the origin and contribution of the thermal, karst, and saltwater end-members under different conditions. Water-stable isotopes $\left(\mathrm{D} / \mathrm{H},{ }^{18} \mathrm{O} /{ }^{16} \mathrm{O}\right)$ were used to quantify the contribution of the saltwater end-member, whereas strontium isotopes $\left({ }^{87} \mathrm{Sr} /{ }^{86} \mathrm{Sr}\right)$ were used to distinguish the origin of salinity (thermal or marine). Rare earth elements (REEs) were used to establish the chemical signature of the thermal wells in a reference context and to evaluate the influence of the marine signature over time. Finally, the B-isotope signature $\left(\mathrm{d}^{11} \mathrm{~B}\right)$ was used to trace water-rock interaction initiated during inversac events. Overall, this approach supported the development of a revised new conceptual model of the site and provided new insights into the management of the groundwater resources.

\section{Study area and geological setting}

The Balaruc peninsula is located along the Mediterranean coast of southernmost France, west of the city of Montpellier (Fig. 1a). The karst aquifer of the peninsula lies within the Middle and Upper Jurassic carbonates that outcrop to the north in the Aumelas Causse and the Gardiole Massif. These Jurassic carbonates are buried under Miocene to Plio-Quaternary deposits in the eastern part of the Thau Lagoon (Fig. 1b). Karstification and burial of the main Jurassic aquifer are the result of the geological history of the region described below.

A Mesozoic series of Triassic to Early Cretaceous age was deposited during Tethyan rifting (Baudrimont and Dubois, 1977; Debrand-Passard, 1984). The Mesozoic carbonate platform underwent uplift during the Mid-Cretaceous, leading to exhumation that caused erosion of the Early Cretaceous series and strong karstification of the Jurassic carbonates.

The Mesozoic series was successively deformed during the Pyrenean collision phase from Upper Cretaceous to Eocene time (Arthaud and Laurent, 1995; Arthaud and Seguret, 1981; Choukroune et al., 1973; Choukroune and Mattauer, 1978) and the later rifting of the Gulf of Lion (Arthaud et al., 1977; Arthaud and Seguret, 1981; Benedicto et al., 1996; Maerten and Séranne, 1995; Séranne, 1999; Thaler, 

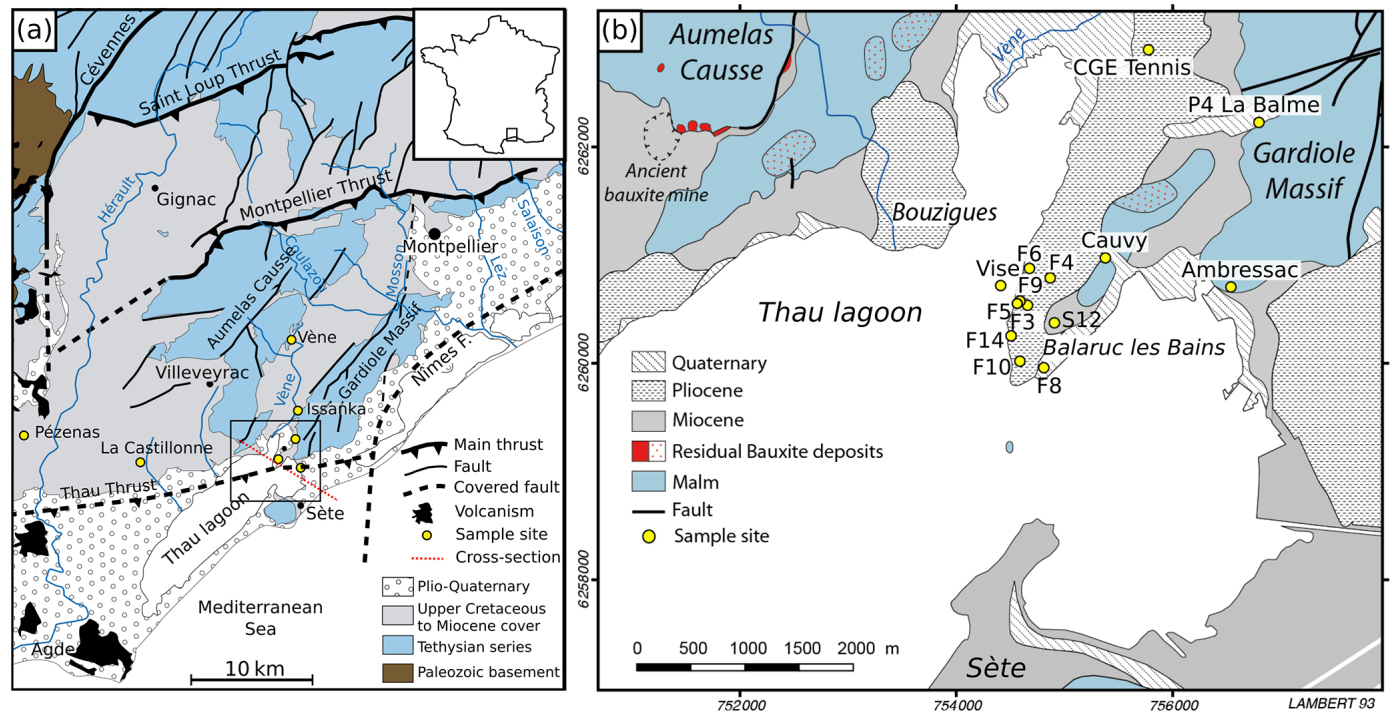

Figure 1. (a) Simplified geological map showing the main structures of the Montpellier region. The box shows the Balaruc-les-Bains study area between the Montpellier Thrust and the Nîmes Fault. (b) Detailed geological map of the eastern Thau Lagoon. Sample sites indicated by the yellow dots in both maps correspond to the locations of the thermal wells, karst springs, and other piezometric drilling sites. The location of the ancient bauxite mine (Cambelliès) is indicated by the dashed oval in the north-west of the study area.

Table 1. Summary of the observed occasional saltwater intrusions (inversac events) in the karst and thermal aquifer of the Thau basin.

\begin{tabular}{|c|c|c|c|}
\hline Date & Duration & Causal factors & End of episode \\
\hline $\begin{array}{l}2014 \\
\text { (May-October) }\end{array}$ & 5 months & $\begin{array}{l}\text { Very low waters. No storm surge in } \\
\text { the lagoon. Groundwater withdrawals }\end{array}$ & $\begin{array}{l}\text { Temporary low water level in } \\
\text { the lagoon combined with } \\
\text { recharge in the karst aquifer }\end{array}$ \\
\hline $\begin{array}{l}2010 \\
\text { (June-December) }\end{array}$ & 7 months & Intermediate waters & Heavy rainfall \\
\hline $\begin{array}{l}2008 \\
\text { (January-March) }\end{array}$ & 3 months & $\begin{array}{l}\text { Low waters and a pump test on } \\
\text { thermal well F14 }\end{array}$ & - \\
\hline $\begin{array}{l}1993 \\
\text { (October) }\end{array}$ & $24 \mathrm{~d}$ & $\begin{array}{l}\text { Low waters. Human intervention } \\
\text { on the submarine spring and } \\
\text { pumping test on the Balaruc } \\
\text { peninsula }\end{array}$ & Heavy rainfall \\
\hline $\begin{array}{l}\text { 1984-1987 } \\
\text { (May-February) }\end{array}$ & 20 months & $\begin{array}{l}\text { Low waters. Lagoon with high } \\
\text { water level. Human intervention on } \\
\text { the griffon of the submarine spring }\end{array}$ & Heavy rainfall \\
\hline $\begin{array}{l}1967 \text { (October)- } \\
1969 \text { (March) }\end{array}$ & $17 / 18$ months & $\begin{array}{l}\text { Dry conditions. Bauxite mining at } \\
\text { the Cambelliès site. Large pumping } \\
\text { (up to } 1000 \mathrm{~m}^{3} \mathrm{~h}^{-1} \text { ) that lowered } \\
\text { the water level to }-20 \mathrm{~m} \text { a.s.l. }\end{array}$ & $\begin{array}{l}\text { Cessation of groundwater } \\
\text { pumping }\end{array}$ \\
\hline
\end{tabular}

1962). Then, the sea level rise of the Early Miocene (Burdigalian) deposited transgressive sediments across the region (Fig. 1b). The overall sedimentary record associated with these Upper Cretaceous to Middle Miocene geological events includes a wide range of detrital and carbonate facies deposited in marine, lacustrine, and fluvial environments (Combes, 1990; Marchand et al., 2020) (Fig. 1a).
The sea level fall related to the Messinian Salinity Crisis caused major river incision across southern France which, as a consequence, deepened the karst system (Clauzon, 1982; Hsu et al., 1973; Ryan, 1976). The Messinian paleovalley in the coastal area was then flooded during the early Pliocene when the Mediterranean was connected again to the Atlantic Ocean. Recent sea level fluctuations over the last $5 \mathrm{Ma}$ 
and associated Plio-Quaternary deposits have generated the present-day morphology of the Thau Lagoon.

Structurally, the Balaruc-les-Bains area is located between both the major NE-trending Cevennes and Nîmes faults, to the south of the Pyrenean Montpellier Thrust (Fig. 1a). The study area is also affected by the presence of the E-Woriented Pyrenean Thau Thrust. The complex fault network at the intersection with the Nîmes Fault allows us to bring the Paleozoic basement at shallow depth (less than $2000 \mathrm{~m}$ according to borehole data) in the Balaruc-Sète area (Fig. 1a).

\section{Hydrogeological conceptual model of the Thau hydrosystem}

The Balaruc peninsula is located at the point of natural convergence of different types of waters, including seawater from the Thau Lagoon and Mediterranean Sea, cold karst groundwater sourced from the Aumelas Causse and Gardiole Massif, and mineralized hot thermal water rising from depth in the Balaruc peninsula (Aquilina et al., 2002). These different types of water interact together in the Middle to Upper Jurassic carbonate reservoir. The Montpellier Thrust to the north of the study area (Fig. 1a) brings impermeable marly Lias to the surface, which delimits the aquifer and acts as a barrier to groundwater circulation. Groundwater flow follows a general N-S trend from the Aumelas Causse and Gardiole Massif to the Balaruc peninsula and the Mediterranean Sea. A clear hydraulic connection from the Vène spring (Aumelas Causse) to Issanka spring (western slope of the Gardiole Massif) has been demonstrated through artificial tracer testing (Bonnet and Paloc, 1969; Ladouche et al., 2001). The main outlets of the Aumelas Causse karst network are the Vise submarine spring, the Issanka spring, and the Vène spring which acts as an overflow outlet. The Vise submarine spring is located on the floor of the Thau Lagoon at $30 \mathrm{~m}$ depth and constitutes the most downgradient discharge feature of the hydrological system. The western part of the Gardiole Massif is drained by the Vise spring as well as Cauvy and Ambressac springs.

At the regional scale, four levels of groundwater circulations have been recognized by previous studies (Aquilina et al., 2003): (1) a surficial groundwater flow component originating from the recharge areas that has a residence time $<20$ years; (2) an intermediate groundwater flow system from the Aumelas Causse that circulates below the Montbazin-Gigean basin and the Gardiole Massif and discharges at points along the continental shelf (residence time of 50 years); (3) a deep regional groundwater flow system directed from the Aumelas Causse to the Villeveyrac Basin, where several deep drillings (Pézenas and La Castillonne, depth of $1000 \mathrm{~m}$ ) present hot karstic waters with low mineralization (residence time of several thousand years); (4) a very deep ( $>2 \mathrm{~km}$ ) paleo-karst water circulation mixed with an ancient seawater circulation both recharging the thermal reservoir that has residence times of the order of 100000 years.

\section{Material and methods}

\subsection{Hydrogeological monitoring}

Water level, specific electrical conductivity, and temperature were measured at 10 locations on an hourly basis during the last three inversac events in 2008, 2010, and 2014. The time-series data used in this study come from the national quantitative groundwater monitoring network of the AFB/BRGM (available on the ADES website: https://ades.eaufrance.fr, last access: 14 June 2020) for P4 La Balme (location 10166X0253) and CGE Tennis (location 10166X0212). Other observation stations (F5, F6, F8, F9, and S12) are managed by Balaruc-les-Bains and the municipality of Sète and the Syndicat Mixte du bassin de Thau (El Cantou, F5-Issanka, Frescaly, and Cauvy).

In order to compare the different inversac events, hydraulic head and electrical conductivity were expressed with respect to reference values observed before the inversac events, as discussed in the Results section below. In Figs. 3 and 5b$\mathrm{d}$, the $x$ axis corresponds to the number of hours elapsed since the beginning of the inversac event $\left(t_{0}\right)$. The $y$ axis represents the difference between the parameter (hydraulic head or electrical conductivity) measured during the inversac and the preceding respective reference values. The variable "delta $\mathrm{H}$ " is the difference between hydraulic head measured at time $=$ " $t$ " and hydraulic head observed at time $=t_{0}$ (before the inversac event). Thus, a positive value corresponds to an increase compared to the baseline condition and vice versa. This relative comparison permits the evaluation of the inversac event perturbations with respect to the initial conditions prevailing in the system and results in a more precise valuation of the transient states of the system.

\subsection{Geochemical and isotopic analysis}

Geochemical data for the 1996-2000 period are from Aquilina et al. $(2002,2003)$ and Ladouche et al. (2001). They are considered representative of reference geochemical conditions of the karst system. Indeed, these data were collected 3 to 7 years after the 1993 inversac, which is considered a sufficient time for the system to have returned to its equilibrium state given the short, $21 \mathrm{~d}$ interval of this event.

New geochemical data (major ions and REE compositions) and isotope analyses $\left(\mathrm{D} / \mathrm{H},{ }^{18} \mathrm{O} /{ }^{16} \mathrm{O},{ }^{3} \mathrm{H},{ }^{87} \mathrm{Sr} /{ }^{86} \mathrm{Sr}\right.$, and $\mathrm{d}^{11} \mathrm{~B}$ ) were determined for samples collected in October 2010, April and September of 2012, and March and August of 2018, i.e. during the 2010 inversac, 17 and 22 months after the end of the 2010 inversac, and 3.5 years after the end of the 2014 inversac.

Temperature, $\mathrm{pH}$, dissolved oxygen, and electrical conductivity $\left(T_{\text {ref }}=25^{\circ} \mathrm{C}\right)$ were measured in the field us- 
ing a portable $\mathrm{pH}$ meter, oxymeter, and conductivity meter (WTW 3210).

Water samples for major and trace element analysis were filtered on-site with a disposable PP syringe with a $0.22 \mu \mathrm{m}$ Durapore membrane and stored in acid-washed HDPE bottles. Aliquots for cations and trace elements were acidified to $\mathrm{pH} 2$ with ultrapure $\mathrm{HNO}_{3}(1 \%$ v/v). Samples for $\mathrm{H}$ - and $\mathrm{O}$-isotope analysis were collected in $15 \mathrm{~mL}$ amber glass vials capped with airtight lids. One litre samples were collected for B- and Sr-isotope analysis in pre-cleaned HDPE bottles and were later filtered in a clean room through a $0.22 \mu \mathrm{m}$ Durapore membrane in a pressurized Nalgene filtration unit, with samples for $\mathrm{Sr}$-isotope analysis acidified with $1 \%$ ultrapure $\mathrm{HNO}_{3}$. Samples for tritium measurement were collected in $1 \mathrm{~L}$ HDPE bottles. All samples were stored at $4{ }^{\circ} \mathrm{C}$ before analysis. Chemical analyses were performed in the HydroSciences Montpellier laboratory at the University of Montpellier. Total alkalinity was measured by acid titration with $0.1 \mathrm{~N} \mathrm{HCl}$. Major ions $\left(\mathrm{Cl}^{-}, \mathrm{NO}_{3}^{-}, \mathrm{SO}_{4}^{2-}, \mathrm{Ca}^{2+}, \mathrm{Mg}^{2+}, \mathrm{Na}^{+}\right.$, and $\mathrm{K}^{+}$) were analysed by ion chromatography (ICS 1000 Dione ${ }^{\circledR}$ ). Precision error was $< \pm 5 \%$. After acidification with $1 \% \mathrm{HNO}_{3}^{-}$, trace elements ( $\mathrm{Li}, \mathrm{B}, \mathrm{Sr}$, REEs, and $\mathrm{U}$ ) were analysed by inductively coupled mass spectrometry using a Thermo Scientific ${ }^{\circledR}$ iCAP Q at the AETE-ISO technical platform of the OSU OREME at the University of Montpellier. The use of an in-line Argon Gas Dilution system permits the direct injection of highly mineralized samples without prior dilution. Precision error was typically $<5 \%$. Freshwater reference material SLRS-6 and seawater reference materials CASS-6 and NASS-6 for trace metals (National Research Council, Canada) were analysed every 20 samples to monitor analytical accuracy. Mean results are within the range of certified uncertainties. Precision error for all analyses was typically $<5 \%$. The REE data are represented in profiles, after normalization to a reference geological material, the North American Shale Composite (NASC) for natural waters, which corresponds to an average sample of North American shales (Taylor and McLennan, 1985).

For stable isotope analysis, samples collected in 2010 were analysed at BRGM Laboratories using a Finnigan MAT 252 mass spectrometer, whereas those collected in 2012 and 2018 were measured on an Elementar Isoprime stable isotope mass spectrometer at the LAMA laboratory of HydroSciences Montpellier at the University of Montpellier. Calibration was performed by repeated analyses of in-house standards of known isotopic composition in alternation with samples. Oxygen $\left({ }^{18} \mathrm{O} /{ }^{16} \mathrm{O}\right)$ and hydrogen $(\mathrm{D} / \mathrm{H})$ isotope ratio measurements are expressed in parts per thousand (i.e. \%o) in the familiar $\delta$ notation relative to the Vienna Standard Mean Ocean Water (SMOW) standard, where $\delta=$ ( $\left.\left[R_{\text {sample }} / R_{\text {standard }}-1\right] \times 1000\right)$. Samples analysed by BRGM have a precision of $\pm 0.8 \%$ o for $\delta \mathrm{D}$ values and $\pm 0.1 \%$ o for $\delta^{18} \mathrm{O}$ values, whereas those determined at the University of Montpellier have an overall precision of $\pm 0.6 \%$ for both $\delta \mathrm{D}$ and $\delta^{18} \mathrm{O}$ values. Tritium analyses were performed at the hy- drogeology laboratory at the Avignon and Pays du Vaucluse University.

Sr-isotope analyses were made by thermal ionization mass spectrometry at BRGM Laboratories for the 2010 samples and at the Centre de Recherches Pétrographiques et Géochimiques in Nancy for the 2012 samples. Chemical separation of $\mathrm{Sr}$ was done using a $\mathrm{Sr}-\mathrm{Spec}$ ion-exchange column that has a total blank $<0.5 \mathrm{ng}$ for the entire chemical separation procedure. Around $150 \mathrm{ng}$ of purified $\mathrm{Sr}$ was loaded onto a tungsten filament and analysed with an average internal precision of $\pm 10 \times 10^{-6}(2 \sigma)$ using a Finnigan MAT262 multiple collector thermal ionization mass spectrometer. Measured ${ }^{87} \mathrm{Sr} /{ }^{86} \mathrm{Sr}$ ratios were normalized to a ${ }^{86} \mathrm{Sr} /{ }^{88} \mathrm{Sr}$ ratio of 0.1194 . The reproducibility of ${ }^{87} \mathrm{Sr} /{ }^{86} \mathrm{Sr}$ ratio measurements was tested through replicate analyses of the NBS987 standard (0.710240) for which the mean value was $0.710232 \pm 22 \times 10^{-6}$ at BRGM and $0.710262 \pm 13 \times$ $10^{-6}$ at the CRPG.

Boron isotopic ratios were measured with a Neptune+, Thermo Electron inductively coupled mass spectrometer at BRGM Laboratories for samples collected in 2010 (Guerrot et al., 2011) and at the AETE-ISO technical platform of the OSU OREME at University of Montpellier for the other samples. The average value determined for the NIST SRM 951 standard was $4.67 \pm 0.0033$.

\section{Results}

\subsection{Revised conceptual model for the Thau hydrosystem}

The conceptual hydrogeological model of the Thau system at the local scale of the Balaruc-les-Bains peninsula is summarized in Fig. 2. Thermal waters rise from the deep reservoir along inferred faults in the vicinity of the Balaruc peninsula to reach the top of the Jurassic aquifer. Consistent with the recent data compilation and results acquired in the Balarucles-Bains area by the Dem'eaux Thau project (Ladouche et al., 2019), we propose that the Thau Thrust is likely to provide the main pathway for thermal water. The karst freshwater is found below this thermal lens as these cold waters are more dense. The diffuse intrusion of marine waters from the Mediterranean Sea into the Jurassic limestone corresponds to a saltwater wedge and is located below the karst waters, which have a lower density. This saltwater wedge can nevertheless have a more complex geometry than that represented in Fig. 2, since this heterogeneous karst system is made up of multiple compartments. These contrasts in water density generate several hydraulic interfaces that change according to the different hydraulic heads resulting from continually varying lagoon water levels, groundwater withdrawals, and recharge from precipitation.

This hydrogeological setting illustrated in Fig. 2 was confirmed by the F13 exploratory well (Table 2) that dis- 


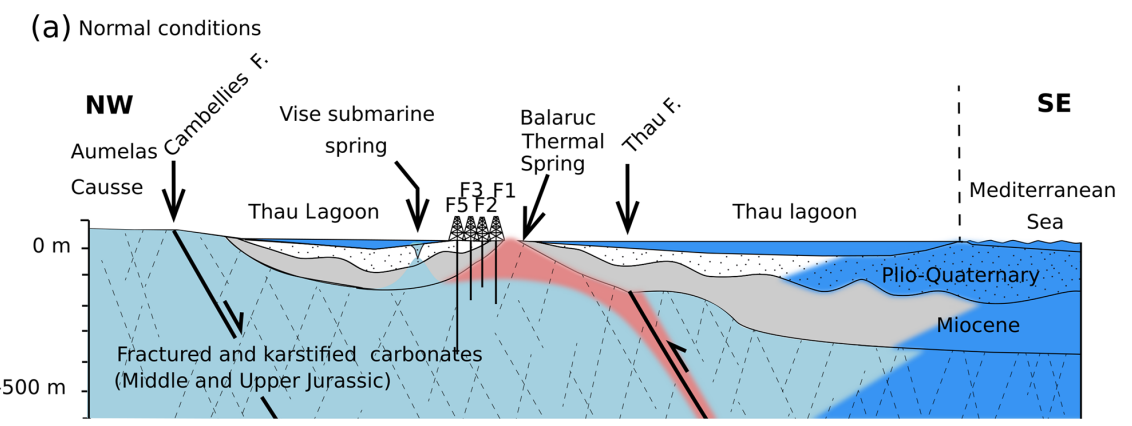

(b) Inversac conditions

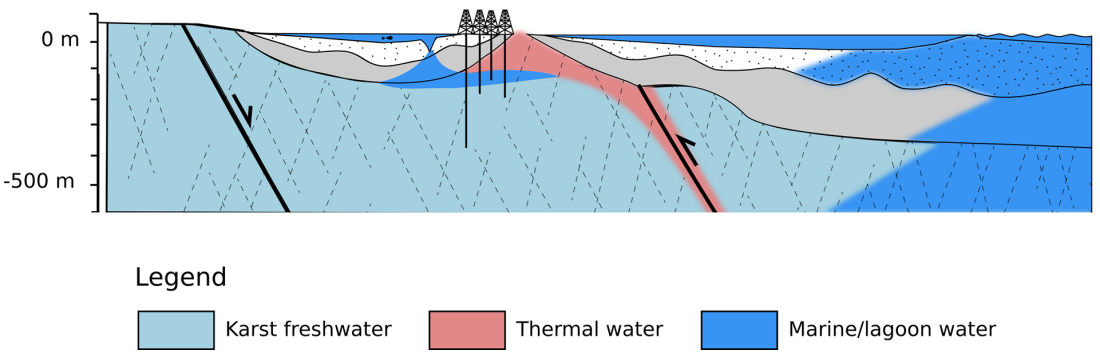

Figure 2. Conceptual cross section oriented NW-SE passing through thermal wells of the Balaruc peninsula and showing groundwater flows of the karst hydrosystem under (a) normal conditions and (b) inversac conditions. Location of the cross section is indicated in Fig. 1a.

Table 2. Water temperature and electrical conductivity from the exploratory drilling F13 at different depths. This inclined well $\left(40^{\circ} \mathrm{NW}, 320^{\circ} \mathrm{N}\right)$ is located near the F14 well (Fig. 1b).

\begin{tabular}{lrc}
\hline $\begin{array}{l}\text { Linear depth } \\
(\mathrm{m})\end{array}$ & $\begin{array}{r}\text { EC } \\
\left(\mathrm{mS} \mathrm{cm}^{-1}\right)\end{array}$ & $\begin{array}{r}\text { Temperature } \\
\left({ }^{\circ} \mathrm{C}\right)\end{array}$ \\
\hline 85 & 16.5 & 25 \\
145 & 1 & 23 \\
223 & 1 & 37 \\
237 & 1 & 37 \\
249 & 2 & 37 \\
297 & 3.2 & 37 \\
389 & 35 & 37 \\
\hline
\end{tabular}

played contrasting electrical conductivity and temperature over depth.

Under normal hydrologic conditions (Fig. 2a), groundwater from the karst aquifer discharges into the Vise spring, creating a plume of freshwater in the lagoon. During an occasional episode of saltwater intrusion (or "inversac" event), the natural flow is reversed and saltwater from the Thau Lagoon flows into the Vise spring and enters the karstic aquifer via the Miocene cover (Fig. 2b). The equilibrium between the different water bodies inside the Jurassic reservoir is then strongly disrupted and the outflow of the karstic system through the Vise spring is prevented. The characteristics of the thermal and karstic wells and spring in the Balarucles-Bains peninsula are shown in Table 3.

\subsection{Hydraulic impact of the inversac event}

This section provides a detailed hydrodynamic analysis of the most recent inversac event in 2014 and then makes a comparison between the last three inversac events of 2008, 2010, and 2014.

The hydraulic impact of the inversac event of 2014 was observed at all Balaruc peninsula springs and observation wells (Fig. 3). From the first hours after the intrusion of lagoon water, a sharp increase in water level is observed for both karst and thermal wells, although the impact is variable for the different locations. The hydraulic impact was most significant for thermal well F9, for which a $+2.2 \mathrm{~m}$ increase in hydraulic head was observed during the first four days of the inversac event. The magnitude of the hydraulic impact is similar for F5 and F6 wells, with experienced respective increases in hydraulic head of +1.8 and $+1.9 \mathrm{~m}$. A lower increase in hydraulic head of just $+0.7 \mathrm{~m}$ during the first four days of the inversac event was recorded at the Cauvy spring, situated only $1 \mathrm{~km}$ from the Vise submarine spring. For this spring, the increase is also partly caused by the interruption of water pumping. The hydraulic disturbance gradually increases over a 3-month period for the CGE Tennis and P4 La Balme wells, reaching a maximum of $2 \mathrm{~m}$ at CGE and around $1 \mathrm{~m}$ at $\mathrm{P} 4 \mathrm{La}$ Balme piezometers after $1500 \mathrm{~h}$.

Two large rainfall events occurred in September and October 2014, some $3400 \mathrm{~h}$ after the beginning of the inversac event. These resulted in recharge to the aquifer that caused a sharp increase in well water levels of $+1.3 \mathrm{~m}$ at CGE Tennis and $+1 \mathrm{~m}$ at $\mathrm{P} 4 \mathrm{La}$ Balme. 
Table 3. Characteristics of the main wells and springs in the study area.

\begin{tabular}{llrlr}
\hline $\begin{array}{l}\text { Name and BRGM } \\
\text { location reference } \\
\text { number }\end{array}$ & $\begin{array}{l}\text { Main water } \\
\text { type }\end{array}$ & $\begin{array}{r}\text { Well } \\
\text { depth } \\
(\mathrm{m})\end{array}$ & $\begin{array}{l}\text { Depth to } \\
\text { the top } \\
\text { of the } \\
\text { karst } \\
\text { aquifer } \\
(\mathrm{m})\end{array}$ & $\begin{array}{r}\begin{array}{r}\text { Distance } \\
\text { from the } \\
\text { Vise }\end{array} \\
\text { submarine } \\
\text { spring } \\
(\mathrm{m})\end{array}$ \\
\hline F5 (10165X0185) & Thermal & 105 & -72 & 325 \\
F6 (10165X0251) & Karst/thermal & 63.5 & -58.5 & 330 \\
F9 (10165X0252) & Thermal & 120 & -88 & 375 \\
F3 (10165X0183) & Thermal & 175 & -65 & 380 \\
F4 (10165X0184) & Thermal & 55 & -38 & 460 \\
F14 (10165X0257) & Thermal & 300 & -170 & 585 \\
F8 (10165X0234) & Thermal & 407 & -136 & 930 \\
Cauvy spring (10165X0021) & Karst & 0 & 0 (outcrop) & 1000 \\
CGE Tennis (10166X0212) & Karst & 115 & -95 & 2600 \\
P4 La Balme (10166X0253) & Karst & 100 & 0 (outcrop) & 2800 \\
Frescaly (10162X0194) & Karst & 54 & -22 & 3400 \\
F7-Issanka (10162X0184) & Karst & 58 & -12 & 4000 \\
F5-Issanka (10162X0136) & Karst & 27 & -14 & 4450 \\
El Cantou (10162X0197) & Karst & & & 4535 \\
\hline
\end{tabular}

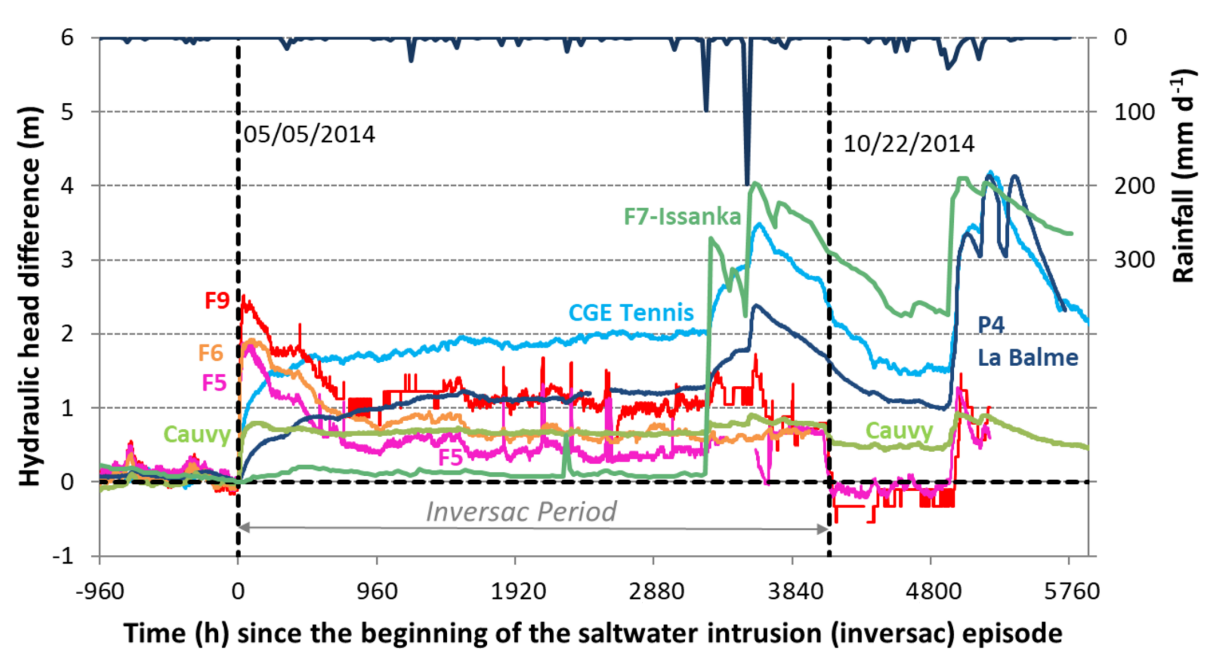

Figure 3. Evolution of variations in hydraulic heads (m) of wells and springs across the study area during the 2014 inversac event. The rainfall record during this time is shown at the top of the figure.

The end of the inversac event occurred in October during the normal recession period of the groundwater levels across the region. The thermal wells experienced a rapid decrease in hydraulic head, which contrasted with the slow decrease in water levels in the CGE Tennis, P4 La Balme, and F7-Issanka wells. After the inversac event, the water levels in the CGE Tennis, P4 La Balme, and Cauvy springs were observed in an intermediate position between the maximum inversac and reference levels. In addition, the analysis of the water levels in the Thau Lagoon by Ladouche and Lamotte (2015) indicates that the end of the 2014 inversac resulted from strong Tramontane winds that caused an abrupt decrease in the la- goon water level in the vicinity of the Vise submarine spring. Thus, both a temporary condition of a low water level in the Thau Lagoon and high-water conditions in the karst aquifer following heavy rainfall events appear to have contributed to the conclusion of the 2014 inversac event.

In the Villeveyrac Basin area, the evolution of piezometric levels during 2014 indicates that the hydrology of this region was not affected by the inversac event (Ladouche and Lamotte, 2015). The elevated piezometric level of some $70 \mathrm{~m}$ here compared to the Vène area $(3 \mathrm{~m})$ strongly suggests a compartmentalization of the karst aquifer. 


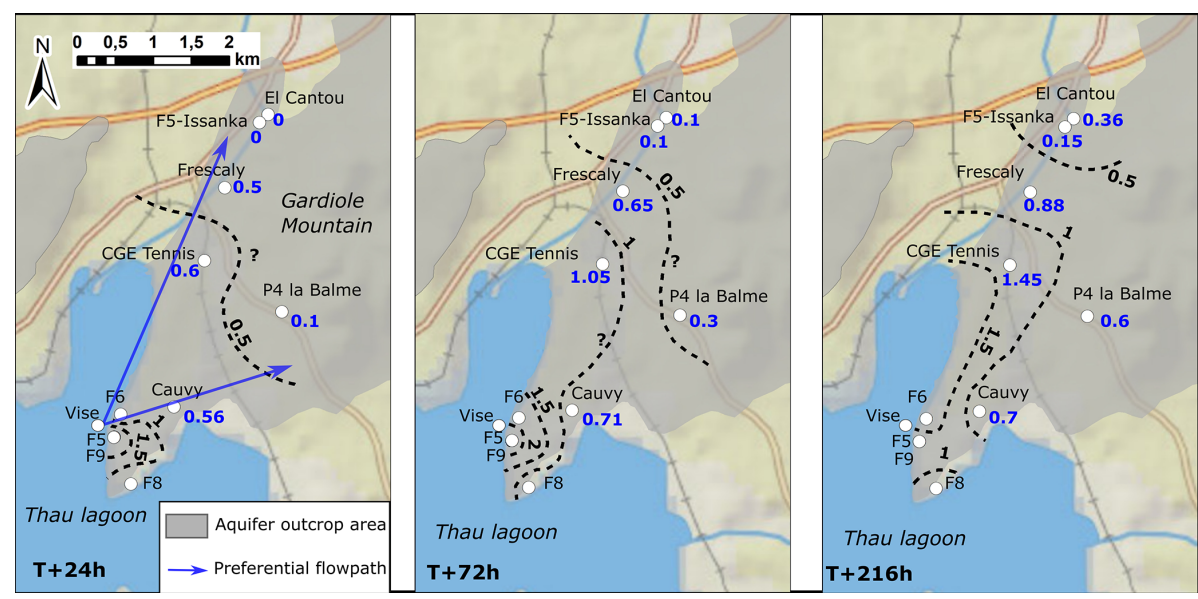

Figure 4. Spatial propagation of the hydraulic perturbation (hydraulic head increase in metres) across the Balaruc-les-Bains peninsula during the 2014 inversac event at three times after initiation: $T+24, T+72$, and $T+216 \mathrm{~h}$.

Figure 4 illustrates the dynamics of the hydraulic disturbance to the karst system caused by the 2014 inversac event across the Balaruc-les-Bains peninsula. This detailed analysis demonstrates the hydrologic connection between the Vise spring and the Issanka area. This perturbation propagates rapidly and reaches a distance of $3 \mathrm{~km}$ upgradient in less than $24 \mathrm{~h}$ (i.e. a velocity of $125 \mathrm{~m} \mathrm{~h}^{-1}$ ). More specifically, the inversac causes an increase in hydraulic head of $+1.5 \mathrm{~m}$ throughout the peninsula and $+0.5 \mathrm{~m}$ to the north of the peninsula (Frescaly, CGE Tennis) in the first $24 \mathrm{~h}$. This hydraulic perturbation then reaches the Issanka area in less than $72 \mathrm{~h}$ (i.e. a velocity of $69 \mathrm{~m} \mathrm{~h}^{-1}$ ) and causes a $+0.4 \mathrm{~m}$ increase in hydraulic head within $10 \mathrm{~d}$.

In addition, Fig. 4 clearly shows that the hydraulic perturbation follows a preferential pathway with a NNE orientation. A second minor flowpath follows an ENE orientation from the Vise spring towards the Cauvy and Ambressac springs.

\section{Comparison between the 2008, 2010, and 2014 inversac events}

Comparison between the last three inversac events of 2008, 2010, and 2014 provides a basis for examining the hydraulic response to the phenomenon under different hydrological states. The 2008 inversac caused an increase in the hydraulic heads of all the wells and piezometers in the study area. For example, karst wells P4 La Balme and CGE Tennis showed respective increases in the hydraulic head of +2 and $+1 \mathrm{~m}$.

The increase in the water levels reached the same wells during the 2014 inversac as in 2008 but was generally lower (more than $1 \mathrm{~m}$ for P4 La Balme and Frescaly and about $0.4 \mathrm{~m}$ in the Issanka area).

In contrast to the 2008 and 2014 events, the hydraulic impact of the 2010 inversac did not reach the Issanka area. An increase in hydraulic heads ranging from 1.5 to $2 \mathrm{~m}$ was only observed north of the Balaruc-les-Bains peninsula for the P4 La Balme and CGE Tennis wells. The explanation for this observation is given in the Discussion section.

The hydraulic head of karst well P4 La Balme was higher during the 2010 inversac (intermediate waters) than during the 2014 inversac (very low waters), reflecting contrasting hydrologic conditions during these periods (Fig. 5a). However, the hydraulic head difference, with respect to the reference measured before the inversac (Fig. 5b), is higher in 2014 than in 2010. This suggests that the low water conditions magnify the hydraulic impact of inversac events. Similarly, electrical conductivity differences for thermal wells F5 (Fig. 5c) and F9 (Fig. 5d) show a stronger response to the 2014 inversac than to both the 2008 and 2010 inversacs.

\subsection{Geochemical impact of the inversac event}

In addition to the hydraulic impact just described, inversac events also have a notable geochemical impact on the water bodies circulating within the karst system. As indicated in the discussion of the "Hydrogeological conceptual model" section, the salty and highly mineralized water of the lagoon mixes with thermal and karst waters to alter their quality. A multi-tracer approach was undertaken to determine the long-term hydrochemical impact of inversac events on the system that employed analysis of major ion contents, REE concentrations, and $\mathrm{H}-, \mathrm{O}-, \mathrm{Sr}-$, and B-isotopic compositions. The geochemical analyses reflect contrasting conditions: the 1996-2000 reference interval, the 2010 inversac event, and the 2012 and 2018 post-inversac periods.

\subsubsection{Groundwater characteristics - major ions and water types}

Outside of the Balaruc peninsula, karst groundwater from the Issanka spring and Pézenas deep borehole $(738 \mathrm{~m})$ is of a 

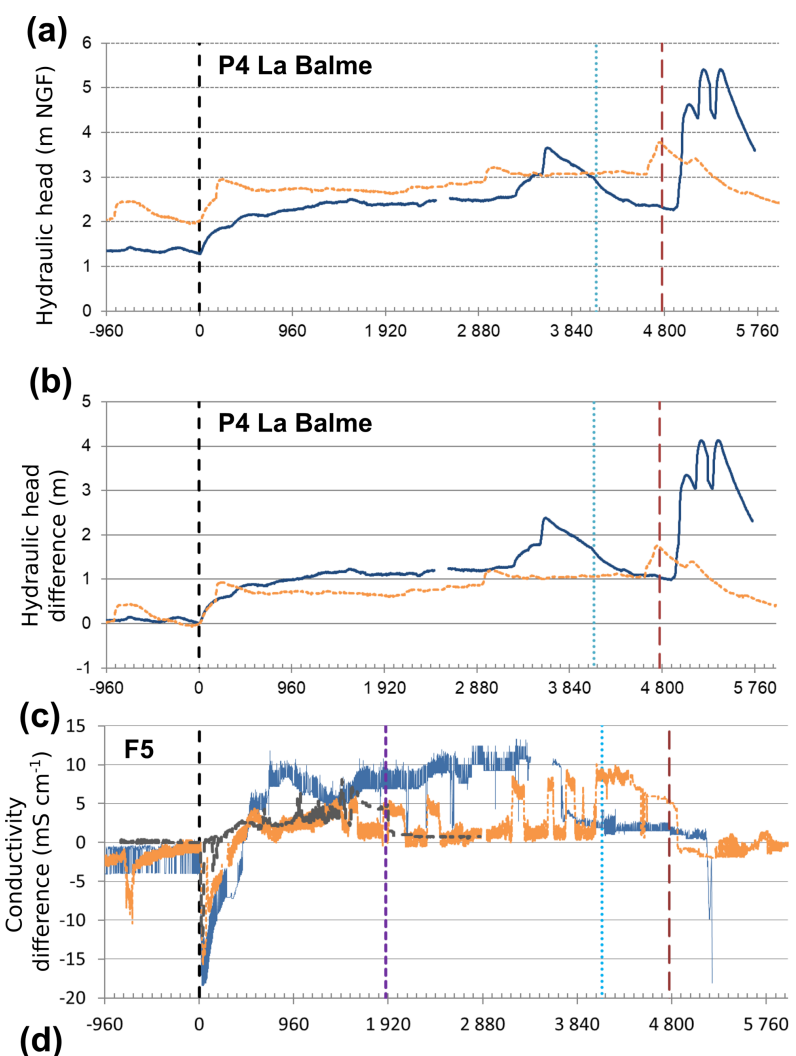

(d)

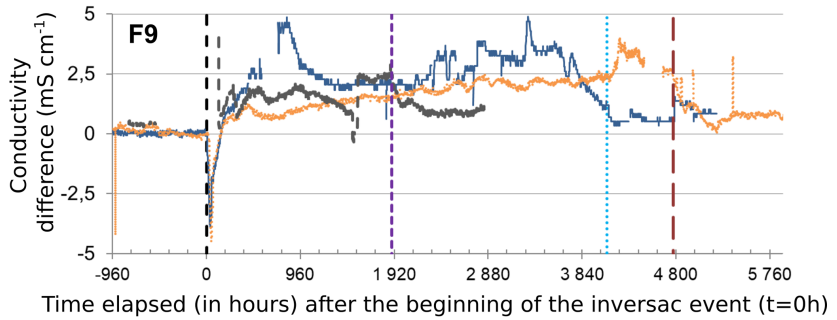

\section{Legend}

$$
\begin{aligned}
& -\quad 2008 \text { data } \\
& -\quad 2010 \text { data } \\
& - \text { - }
\end{aligned}
$$

Figure 5. (a) Hydraulic head (m) and (b) hydraulic head variation (m) of karst well P4 La Balme during the 2010 and 2014 inversac events; electrical conductivity variation $\left(\mathrm{mS} \mathrm{cm}^{-1}\right)$ for thermal wells (c) F5 and (d) F9 during the 2008, 2010, and 2014 inversac events.

$\mathrm{Ca}-\mathrm{Mg}-\mathrm{HCO}_{3}$ type, characterized by electrical conductivity (EC) values of about $500 \mu \mathrm{S} \mathrm{cm}^{-1}$, in agreement with their karstic water type. The water from the deep borehole has a higher temperature $\left(37.2^{\circ} \mathrm{C}\right)$ than that of the Issanka spring (about $17.5^{\circ} \mathrm{C}$ ).

Within the Balaruc peninsula, karst water from the Cauvy spring is of the same water type but displays elevated $\mathrm{Cl}$ contents and EC values of up to $222 \mathrm{mg} \mathrm{L}^{-1}$ and $1200 \mu \mathrm{S} \mathrm{cm}^{-1}$, respectively. In contrast, the thermal waters with temperatures that range up to $49.9^{\circ} \mathrm{C}$ are of a $\mathrm{Na}-\mathrm{Cl}$ type with
$\mathrm{Cl}$ concentrations of up to $7900 \mathrm{mg} \mathrm{L}^{-1}$. The Ambressac spring, located east of the Balaruc peninsula, is of mixed water type, with higher $\mathrm{Cl}$ concentration than at the Cauvy spring (up to $930 \mathrm{mg} \mathrm{L}^{-1}$ ). Some samples also have high sulfate concentrations that approach $585 \mathrm{mg} \mathrm{L}^{-1}$.

The Cauvy spring and the thermal wells F5, F6, and F9 were the most impacted by the 2010 inversac event, displaying a sharp increase in conductivity as well as high contents of $\mathrm{Cl}$ and $\mathrm{Na}$. For example, $\mathrm{Cl}$ concentrations in the Cauvy spring and F6 reached levels 8 to 11 times above values typical of normal flow conditions (i.e. $1240 \mathrm{mg} \mathrm{L}^{-1}$ compared with $157 \mathrm{mg} \mathrm{L}^{-1}$ for Cauvy and $8611 \mathrm{mg} \mathrm{L}^{-1}$ compared with $759 \mathrm{mg} \mathrm{L}^{-1}$ for F6). For the Cauvy spring, which is used for potable water, this $\mathrm{Cl}$ content observed during the inversac event far exceeds the drinking water standard of $250 \mathrm{~m} \mathrm{~L} \mathrm{~L}^{-1}$.

In a post-inversac context, $\mathrm{Cl}$ and $\mathrm{Na}$ concentrations observed for the Cauvy spring and the F5, F6, and F9 wells in 2012 decreased significantly, with waters at these sampling points having returned to levels close to those of the 1996-2000 reference period. By contrast, $\mathrm{Cl}$ concentrations in wells F8 and F3 increased between 2010 and 2012, suggesting an increase in the relative contribution of the marine water component.

\subsubsection{Karst water and saltwater mixing traced by water-stable isotopes}

As shown in Fig. 6a, different waters present in the Balaruc peninsula hydrosystem are characterized by distinct $\delta \mathrm{D}$ and $\delta^{18} \mathrm{O}$ values. Normal waters within the karst system lie close to the Local Meteoric Water Line $\left(\delta \mathrm{D}=8 \delta^{18} \mathrm{O}+14\right.$; Ladouche et al., 1998), illustrating their meteoric origin. Waters sampled from thermal wells are more enriched in D and ${ }^{18} \mathrm{O}$ than the karst waters and are distributed along a karstsaltwater (i.e. lagoon or seawater) mixing line.

This result indicates that thermal waters result from a mixing between karst and marine end-members. However, stable isotope information alone does not allow a determination of the origin of the marine end-member, which could be either lagoon water or modern or ancient seawater. Samples from the F8 thermal well show a slightly enriched stable isotope signature compared to the other thermal wells, reflecting a greater contribution of the saltwater end-member in this area, as initially indicated by Aquilina et al. (2002).

F6 samples from the reference period are located within the karst water domain, confirming the strong influence of karst waters in this well (Aquilina et al., 2002) under normal flow conditions.

$\mathrm{H}$ - and $\mathrm{O}$-isotopic signatures of groundwater from the $\mathrm{F}$, F9, F8, and F6 thermal wells are shifted towards the saltwater end-member during the 2010 inversac. Then, in 2012 and 2018, their $\delta \mathrm{D}$ and $\delta^{18} \mathrm{O}$ values decreased but still remain in an intermediate position between the inversac maximum and the reference (1996-2000) period minimum. This result raises the question of the persistence of the chemical 


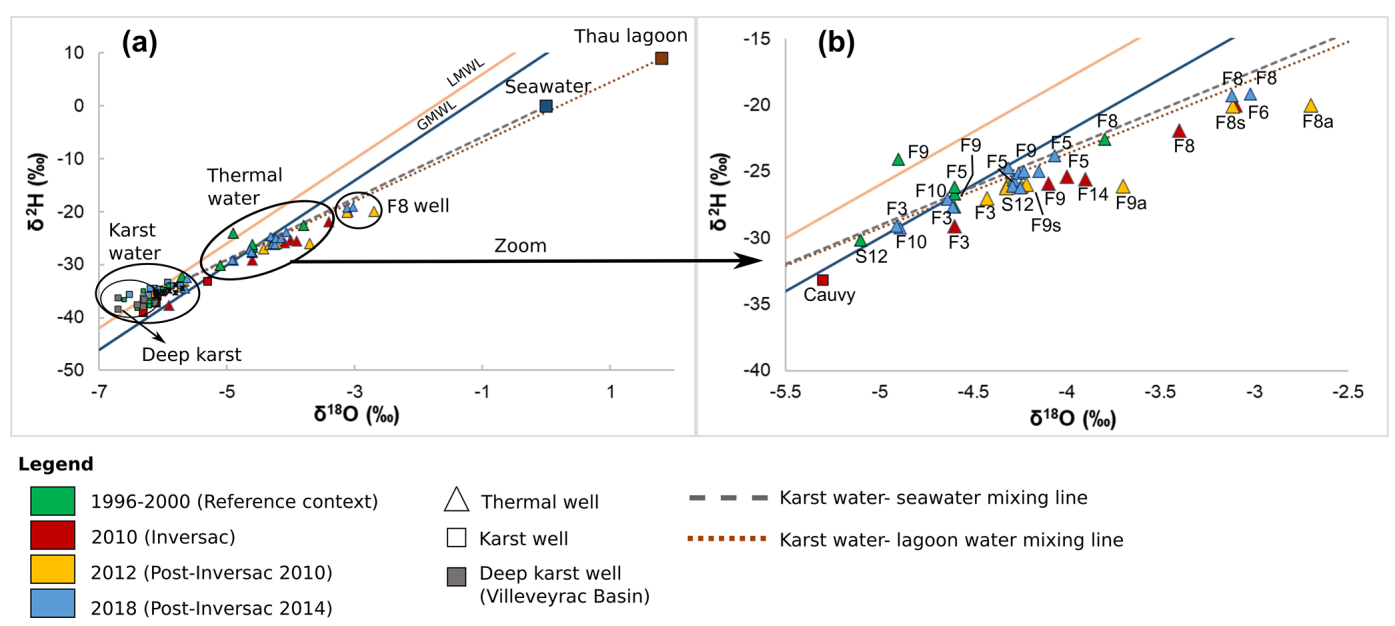

Figure 6. $\mathrm{H}$ - and $\mathrm{O}$-isotopic compositions, expressed as $\delta^{2} \mathrm{H}$ and $\delta^{18} \mathrm{O}$ values, of (a) karst waters, thermal waters, F8 well water, seawater, and Thau Lagoon water, showing the Global Meteoric Water Line (GMWL) after Craig (1961) and the Local Meteoric Water Line (Ladouche et al., 1998) for reference; (b) expanded view of the thermal well water array from (a) during reference, inversac, and post-inversac conditions.

impact in the aquifer system following occasional saltwater intrusions.

Thermal wells F14 and F5 and the thermal spring S12 show similar mixing proportions for the 2012 and 2018 postinversac times. For F5 and S12, these mixing proportions are intermediate between that of the 2010 inversac event and the 1996-2000 reference time. Groundwater samples of the F3 well do not follow the same evolution, as the shift in its $\delta^{18} \mathrm{O}$ value does not appear to be inversac-related (Fig. 6b).

Two end-member mixing calculations were made to model the geochemical impact of the 2010 inversac event on waters at the different sampling points across the study area, the first based on stable isotope ratios and the second using $\mathrm{Cl}$ concentrations measured in 2010, 2012, and 2018. The proportions of karst water $\left(f_{\text {fresh }}\right)$ and saltwater $\left(f_{\text {salt }}\right)$ in a groundwater sample were calculated using the following formula:

$$
\begin{aligned}
& f_{\text {salt }}=\frac{C_{\text {sample }}-C_{\text {fresh }}}{C_{\text {salt }}-C_{\text {fresh }}}, \\
& f_{\text {salt }}+f_{\text {fresh }}=1 .
\end{aligned}
$$

Results of the mixing calculations are included in the Supplement (Table S1). This calculation gives an indication of the magnitude of the karst water and saltwater component in each water sample but does not provide additional insight into the origin of groundwater salinity. The calculated fractions of saltwater for the karst wells and spring are similar for the three tracers $\left(\delta^{18} \mathrm{O}, \delta \mathrm{D}\right.$ and $\left.\mathrm{Cl}\right)$. However, for thermal wells with typical high $\mathrm{Cl}$ contents, the fractions obtained are distinct for the different tracers, indicating another source of $\mathrm{Cl}$ for these wells. Indeed, as indicated by Aquilina et al. (2002), $\mathrm{Cl}$ in the thermal wells is thought to derive from both seawater and the thermal water end-member, which is itself partly constituted of old seawater.

\subsubsection{Inversac persistence revealed by REE}

The 14 members of the lanthanide group of elements (from La to Lu), commonly termed REEs, constitute an effective tool to trace water origin, water-rock interaction, and mixing processes (Johannesson et al., 1997; Tweed et al., 2006; Zhan et al., 2013; Gill et al., 2018). The REEs are naturally present in natural waters at trace concentrations, and their normalized abundances, represented as a distribution pattern of individual REEs ordered by their atomic number, provide a means of visualizing the behaviour of the entire group of elements.

The REE profiles for seawater and groundwater from the thermal wells (S12, F8, F9, F5, F6) and seawater are shown in Fig. 7 for the pre-inversac reference and three post-inversac situations. With the exception of the F6 well, all patterns are generally flat and show a small negative $\mathrm{Ce}$ anomaly. The F6 profile exhibits a more pronounced $\mathrm{Ce}$ anomaly and an enrichment in heavy REEs. These characteristics are those of limestone REE profiles, inherited from the seawater REE profile and confirm the strong karst influence of F6 samples.

REE contents during the 2011-2012 post-inversac period were generally lower than for the 1998 reference context. This is to say that REE profiles in a post-inversac context lie in an intermediate position between the seawater profile and the reference profiles. Such an observation indicates that the thermal wells, at the time of sampling 20 months later in 2012, were still under the influence of the perturbations caused by the 2010 inversac event. The post-inversac profiles for 2012 and 2018 are quite similar, except for the F6 well, suggesting a similarity in the extent of the 2010 and 2014 inversac events and post-event response of the hydrologic system. The REE profile for the F8 thermal well displays a distinctly different evolution, with an increasing shift away from 

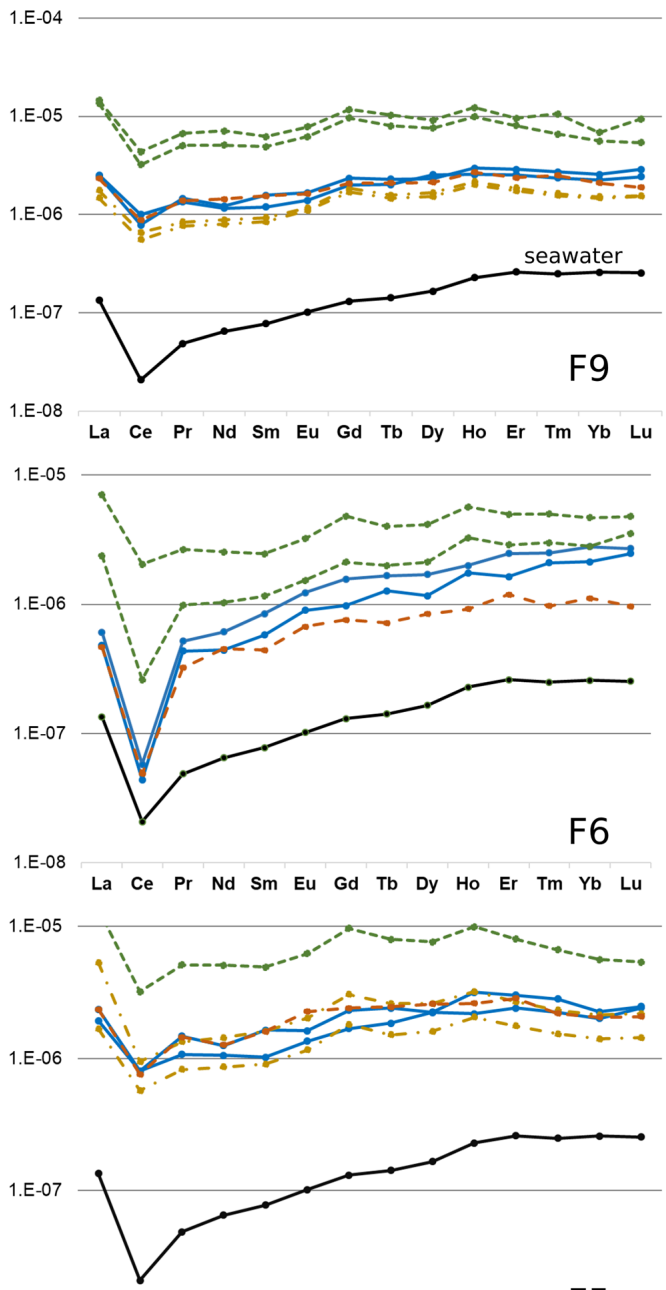

F5

1.E-08

La Ce Pr Nd Sm Eu Gd Tb Dy Ho Er Tm Yb Lu
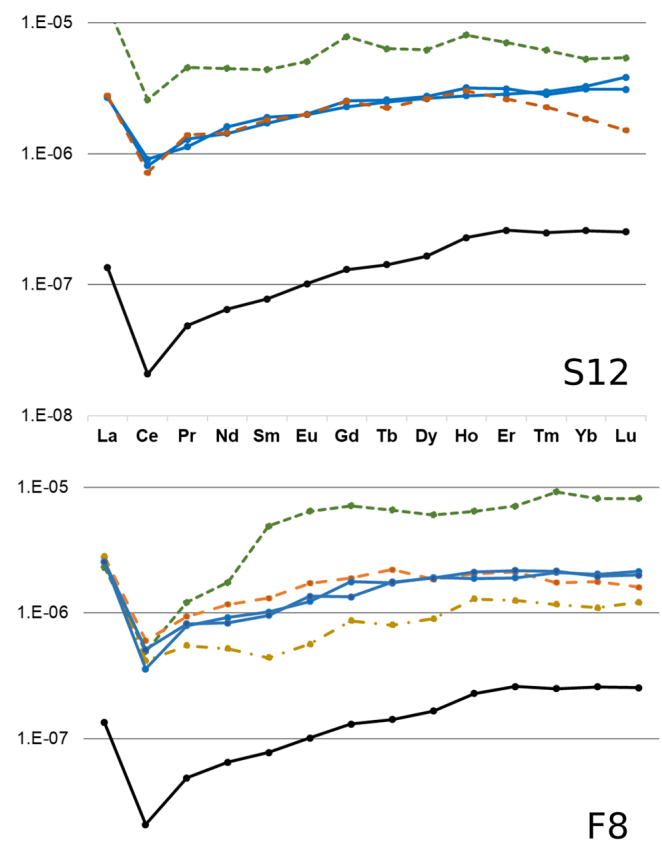

1.E-08

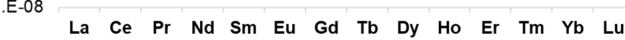

\section{Legend}

- 2018 (after 2014 inversac event)
- - - - 2012 (after 2010 inversac event)
- - - - 1998 (reference, normal context)

Figure 7. REE profiles for thermal wells at different times: the 1998 data are for the pre-inversac reference state, whereas the 2011, 2012, and 2018 profiles are for the three post-inversac situations.

the seawater profile over time. However, this well is not hydraulically impacted by the occasional saltwater intrusion. The observed evolution does not seem related to an increase in water withdrawals but may instead reflect a relative decrease in the contribution of thermal component over time.

\subsubsection{Characterization of the thermal and marine contributions from the strontium isotope ratios ${ }^{87} \mathrm{Sr} /{ }^{86} \mathrm{Sr}$}

Consideration of strontium geochemistry allows the characterization of the thermal and marine water contributions to the karst groundwaters. Sr-isotope ratios $\left({ }^{87} \mathrm{Sr} /{ }^{86} \mathrm{Sr}\right)$ for the groundwater and lagoon samples are plotted as a function of strontium in Fig. 8, where the 2010 and 2012 post-inversac data are compared with the 1996-2000 reference situation. It was assumed that the waters from the F5 thermal well in the Balaruc peninsula during the reference interval are represen- tative of the thermal end-member, which is not affected by the karst or marine waters. It is notable that the Sr-isotopic signature and $\mathrm{Sr}$ content of the CGE Tennis samples are relatively stable in all contexts and fully representative of karst waters under confined conditions. The Thau Lagoon water sample is compositionally similar to that of the Mediterranean Sea and corresponds to the saltwater end-member. The ${ }^{87} \mathrm{Sr} /{ }^{86} \mathrm{Sr}$ isotopic signatures of karst waters and thermal end-members are similar, indicative of derivation through water-rock interaction with the Mesozoic carbonate aquifer. The karst end-member is different from the thermal endmember by its lower $\mathrm{Sr}$ concentrations $\left(100 \mu \mathrm{g} \mathrm{L}^{-1}\right)$, suggesting different water residence times.

As shown in Fig. 8, all water samples plot within a ternary domain, confirming that the geochemistry from the Balaruc peninsula groundwater can be explained by a three-member mixing. The karst waters from the Issanka spring that drain 


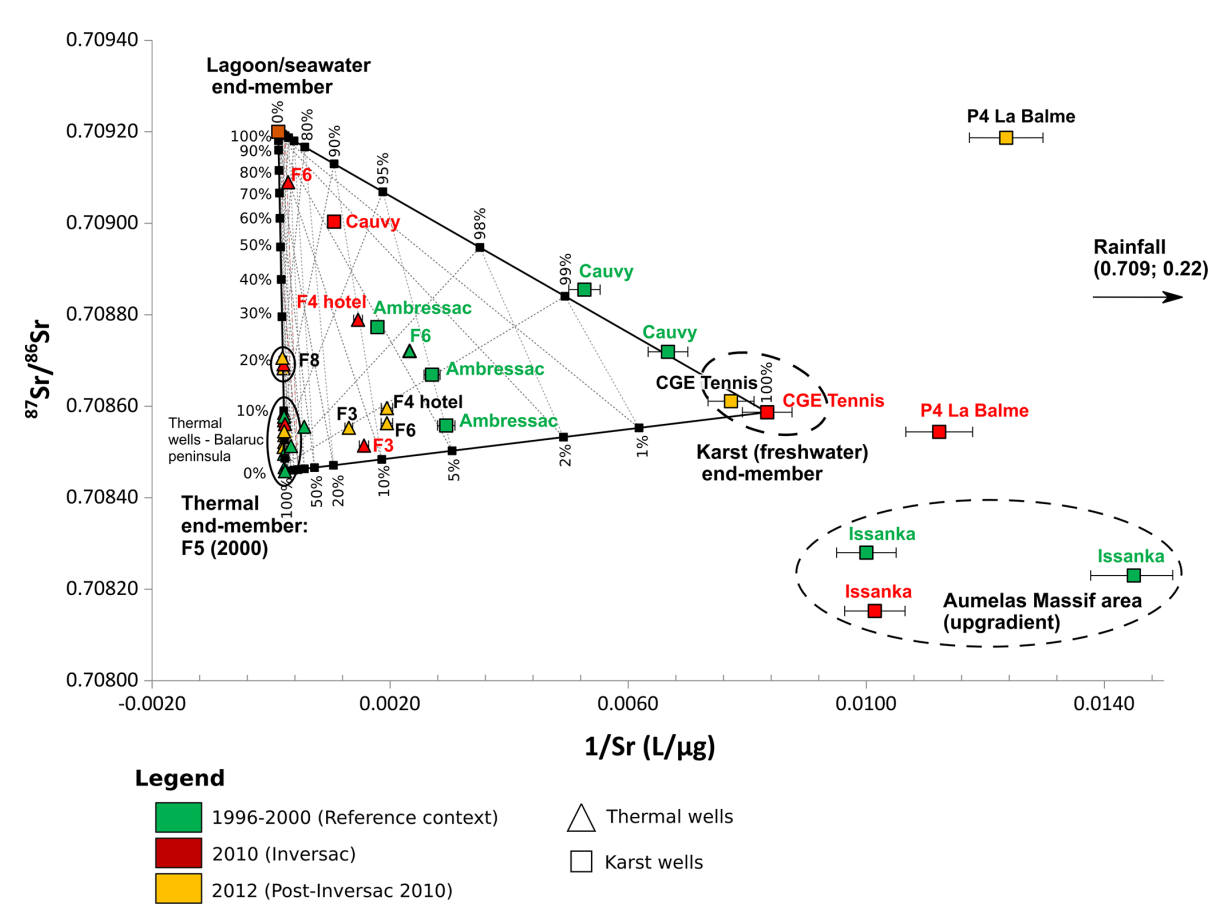

Figure 8. Plot of ${ }^{87} \mathrm{Sr} /{ }^{86} \mathrm{Sr}$ ratio versus $\mathrm{Sr}$ concentration (as 1/Sr) for springs and wells of the Balaruc peninsula for different hydrogeological situations: pre-inversac reference (green), 2010 inversac (red), and 2012 post-inversac (yellow).

the Aumelas Massif have a lower ${ }^{87} \mathrm{Sr} /{ }^{86} \mathrm{Sr}$ ratios and $\mathrm{Sr}$ contents. The Issanka isotopic signature defines an upgradient end-member for the karst system, unaffected by mixings of the thermal and seawater that characterizes the Balaruc peninsula. Waters from the P4 La Balme piezometer had a very high ${ }^{87} \mathrm{Sr} /{ }^{86} \mathrm{Sr}$ ratio in 2012 , almost certainly reflecting the influence of rainfall infiltration since this sample site is located at the outcrop of the aquifer and may be representative of surficial recharge water to the karst aquifer.

The contributions of each end-member (saltwater, thermal water, and karst water) to groundwater samples under different hydrogeological situations related to inversac events were estimated through three-component mass balance equations following Faure (1986):

$f_{\text {salt }}+f_{\text {karst }}+f_{\text {therm }}=1$,

where

$$
\begin{aligned}
\left({ }^{87} \mathrm{Sr} /{ }^{86} \mathrm{Sr}\right) \cdot[\mathrm{Sr}]_{\text {sample }} & =f_{\text {salt }}\left({ }^{87} \mathrm{Sr} /{ }^{86} \mathrm{Sr}\right) \cdot[\mathrm{Sr}]_{\text {salt }} \\
& +f_{\text {karst }}\left({ }^{87} \mathrm{Sr} /{ }^{86} \mathrm{Sr}\right) \cdot[\mathrm{Sr}]_{\text {karst }} \\
& +f_{\text {therm }}\left({ }^{87} \mathrm{Sr} /{ }^{86} \mathrm{Sr}\right) \cdot[\mathrm{Sr}]_{\text {therm }}
\end{aligned}
$$

Results of the mixing calculations are in Table S2.

The Sr-isotopic composition of the Cauvy spring is quite variable during the reference interval, with samples aligned along the karst-saltwater mixing line in Fig. 8. The contribution of the saltwater end-member to the spring discharge is negligible under normal flow conditions, with the Cauvy isotopic signature very close (99\%) to the karst end-member. However, the Cauvy spring is strongly impacted by the inversac phenomenon. Although the karst end-member remains dominant at $88.1 \pm 0.2 \%$, the contribution of the saltwater end-member increases to $8.1 \pm 0.5 \%$ and that of the thermal end-member reaches about $3.8 \pm 0.3 \%$ during the 2010 inversac event. The contribution of thermal waters to the Cauvy spring is not surprising, as it is located close to the old thermal spring (S12), but the large contribution of the saltwater end-member during inversac events implies a preferential groundwater flow axis between the spring and the Vise submarine spring. Pinault et al. (2004) have shown that variations in the contribution of thermal waters may be related to the existence of a piston effect on the thermal reservoir, particularly following an intense recharge event.

Thermal well waters of the Balaruc peninsula are all aligned along the thermal-saltwater end-member mixing line in Fig. 8, except for F3, F4 hotel, and F6 waters, each of which documents a significant contribution from the karst end-member $(87.9 \pm 0.3 \%, 89.8 \pm 0.2 \%$, and $53.7 \pm 0.6 \%$, respectively).

The evolution of the isotopic signature for the F5, F9, and F14 borehole waters shows a similar pattern. Thermal water ${ }^{87} \mathrm{Sr} /{ }^{86} \mathrm{Sr}$ ratios increase during the 2010 inversac event but then decreases in 2012 to values intermediate between the inversac condition and normal state. These observations suggest that waters from this group of thermal wells were strongly affected by the 2010 inversac and had not returned 
to their 1996-2000 pre-inversac Sr-isotope signature by the 2012 post-inversac situation.

The contribution of the Thau Lagoon end-member increased to $8.3 \pm 1.3 \%$ for the F9 waters during the 2010 inversac and the thermal end-member was $91.3 \pm 0.6 \%$, the karstic contribution being negligible $(0.4 \pm 1.9 \%)$. The contribution of the Thau Lagoon end-member decreased to $5.7 \pm$ $1.2 \%$ during the 2012 context.

Reporting on water collected from the F8 borehole, Aquilina et al. (2002) noted a seawater contribution to the thermal waters in this area of the Balaruc peninsula, which we have estimated to be $8.8 \pm 1.3 \%$ for the $1996-2000$ preinversac reference period.

The strontium concentrations and ${ }^{87} \mathrm{Sr} /{ }^{86} \mathrm{Sr}$ ratios of F8 well waters were very similar in 2010 and in April and September of 2012. Although the contribution from the saltwater end-member during the 2010 inversac was greater than the reference condition $(18.0 \pm 1.6 \%$ instead of $8.8 \pm 1.3 \%)$, it remained between $17.5 \pm 1.6 \%$ and $21.2 \pm 1.8 \%$ from April to September 2012. The thermal well F8 does not seem to be impacted by a direct intrusion of lagoon water during the inversac event but instead influenced by seawater already within the hydrosystem.

Water at the F6 borehole was the most impacted by the 2010 inversac. During this time, the contribution from the saltwater end-member sharply increased from $1.6 \pm 0.1 \%$ to $35.4 \pm 1.8 \%$ between 1996 and 2010 and then decreased to $0.6 \pm 0.1 \%$ in 2012 , a value below the 1996 to 2000 reference interval. Waters from the F6 borehole are representative of the upper part of the Jurassic aquifer and demonstrate a significant contribution of the karst end-member $(94.1 \pm 0.1 \%$ to $91.2 \pm 0.2 \%$ in 1996 and 2012). This karst contribution remains significant during an inversac context $(53.7 \pm 0.6 \%)$. Thus, waters from the F6 well illustrate the range of fluctuations of the thermal component.

In contrast to the F6 well, the three end-member contributions are relatively stable for the waters of Ambressac spring. Indeed, water samples display a large variability, with a saltwater end-member contribution of between $1.1 \pm 0.1 \%$ and $2.7 \pm 0.2 \%$ and a karst contribution between $94.4 \pm 0.1 \%$ and $91.5 \pm 0.1 \%$ over the reference interval (1996-2000). The thermal contribution ranges between $4.4 \pm 0.1 \%$ and $5.8 \pm 0.2 \%$ during normal times.

\subsubsection{Boron isotope tracking of water-rock interactions}

A lack of knowledge of the baseline B-isotopic signature during normal flow conditions does not allow us to discuss the origin of boron and its quantification for thermal borehole waters.

However, examination of $\delta^{11} \mathrm{~B}$ variations as a function of $\mathrm{Cl} / \mathrm{B}$ ratio clearly identifies water interactions with clay minerals. Indeed, boron is present in aqueous solution, in the form of boric acid $\mathrm{B}(\mathrm{OH})_{3}$ and borate ions $\mathrm{B}(\mathrm{OH})_{4}^{-}$. The distribution between these two species depends on $\mathrm{pH}$, tem-

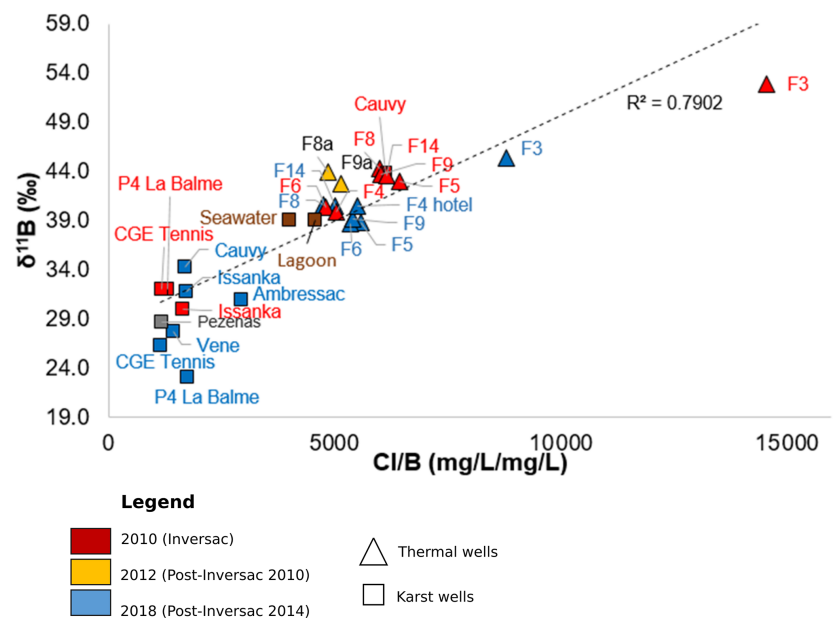

Figure 9. Plot of the $\delta^{11} \mathrm{~B}$ versus $\mathrm{Cl} / \mathrm{B}$ ratio for different hydrogeological contexts: 2010 (inversac times in red) and 2012 and 2018 (post-inversac times in yellow and blue).

perature and salinity (Hershey et al., 1986; Kakihana et al., 1977). For the boron isotopes, ${ }^{11} \mathrm{~B}$ is preferentially incorporated into boric acid, whereas ${ }^{10} \mathrm{~B}$ has a greater affinity for the borate ion. During the water-rock interaction, $\mathrm{B}(\mathrm{OH})_{4}^{-}$ will be preferentially adsorbed onto clay minerals or organic matter, resulting in a decrease in water B concentration and a consequent enrichment of ${ }^{11} \mathrm{~B}$ in residual water.

Figure 9 shows the B-isotopic composition as a function of the $\mathrm{Cl} / \mathrm{B}$ ratio. $\delta^{11} \mathrm{~B}$ of the Thau Lagoon is $39.1 \%$, in agreement with the signature of the modern seawater of 39.5\%o(Aggarwal et al., 2004; Aggarwal and Palmer, 1995). By contrast, karst waters display a range of $\delta^{11} \mathrm{~B}$ values from $23.1 \%$ to $43.8 \%$ out are strongly ${ }^{10} \mathrm{~B}$-enriched relative to seawater signature, whereas, thermal waters have $\delta^{11} \mathrm{~B}$ values of up to $44.3 \%$ o that are similar to or higher than the seawater signature.

There is a good alignment of the data points in Fig. 9, which illustrates the process of water-rock interaction and indicates that the $\mathrm{B}$ in the waters across the Balaruc peninsula is derived from clay sediments. That ${ }^{11} \mathrm{~B} /{ }^{10} \mathrm{~B}$ ratios are well above the seawater values, suggests that water from the Thau Lagoon interacts with clay sediments within the karst system during the occasional intrusion into the carbonate aquifer. An exploration dive of the bottom of the Vise spring in April 2017 showed the absence of sediment on the walls and bottom of the spring. The inversac phenomenon therefore seems to be accompanied by a significant intrusion of sediments (clayey marine mud, rich in organic matter). This phenomenon seems to contribute to initiating the process of boron isotope fractionation. This process could also occur within the silty-clay Miocene unit during the transfer of water from the lagoon to the Jurassic aquifer. This Miocene formation overlies the Jurassic aquifer and is about $30 \mathrm{~m}$ thick at the Vise spring. The high isotopic enrichment observed 
for the F3 borehole waters can be explained by their high $\mathrm{pH}$ values (8.3) and thus a relatively higher proportion of the $\mathrm{B}(\mathrm{OH})_{4}^{-}$species, leading to a higher adsorption on the solid phase and a higher $\delta^{11} \mathrm{~B}$ of the residual water.

Boron isotopes are used to identify the chemical modification of the water that enters the system and interacts with the clay matrix. There is therefore a modification of the water chemistry before it even enters the karst aquifer, and this modification is initiated during the saltwater intrusion.

\section{Discussion}

\subsection{Implications for dynamics of the Thau hydrosystem}

\subsubsection{Extent of the hydraulic impact and conditions required to reach the upgradient area of Issanka}

Analysis of the hydraulic response of the Thau hydrosystem to the last inversac events provides insights into the dynamics of the system and a better understanding of the underlying controlling mechanisms. For example, the 2010 inversac did not impact the upgradient area of Issanka, in contrast to the 2008 and 2014 inversac events. This is attributed to the fact that the karst system in 2010 was less in deficit than at the time of the 2008 and 2014 events, when very lowflow conditions prevailed. For example, piezometric levels measured for the Issanka area in 2008 and 2014 were lower than in 2010 (i.e. $6.82 \mathrm{~m}$ in $2008,6.89 \mathrm{~m}$ in 2014 , and $9.33 \mathrm{~m}$ in 2010). Considering that the overflow level of the Issanka spring is at $\sim 9.5 \mathrm{~m}$, this implies that the hydraulic impact in the Issanka compartment is controlled by the pressure head difference between the upstream (Issanka) and downstream (Balaruc peninsula) compartments. Piezometric monitoring at these different times illustrates that the occurrence of the inversac phenomenon is mainly determined by hydrogeological processes that occur within the downstream compartment of the karst system. Water level of the Thau Lagoon is one of the controlling parameters. At inversac initiation in 2008, the water level in the Thau Lagoon was higher than in 2010 at $1 \mathrm{~m}$ compared to just $0.5 \mathrm{~m}$ but then only of $0.2 \mathrm{~m}$ in 2014. For the inversacs of 2008 and 2010, the sudden rise in lagoon waters of +0.5 and $+0.4 \mathrm{~m}$, respectively, in a few hours is considered to be the triggering factor. By contrast, no sudden change in the water level of lagoon was observed in 2014. The triggering mechanism of this event is still poorly understood; however, it is likely that the withdrawals from the aquifer for drinking water and irrigation purposes as well as the low recharge during the previous winter may be the explanatory factors.

Thus, two factors would need to be combined for an inversac to reach the upgradient area of Issanka: (i) first, low water conditions that produce a very low hydraulic head throughout the aquifer. The hydraulic head would need to be lower than $7 \mathrm{~m}$ in the Issanka area, i.e. below than the hydraulic head im- posed by the saltwater intrusion. (ii) An event-specific triggering mechanism, such as a sudden rise in the water level of the Thau Lagoon or groundwater withdrawals.

The intrusion of lagoon waters in the system causes a twophase response within the Thau hydrosystem:

1. a short initial transient phase of a few days' duration during which there is a reorganization or displacement of the different karst, thermal, and marine water bodies within the hydrosystem, and

2. a longer transient phase during which the hydrosystem reaches a new equilibrium (in $30 \mathrm{~d}$ in 2008 and 2010, $40 \mathrm{~d}$ in 2014), with clear evidence of water mixing causing important changes in the physico-chemical parameters of waters from the sampling points F5, F6, and F9 and the Cauvy spring.

\subsubsection{The impact on water quality is local, whereas the} hydraulic impact is perceived at the regional scale

Results in Sect. 5.2 showed that the hydraulic impact of an inversac event is instantly propagated throughout the Balaruc peninsula, and the effects of such events can also reach longer distances into the karst system than previously described. The return to the equilibrium situation occurs within days after a significant recharge event and is much more rapid than the dissipation of the chemical impact of the inversac event. Indeed, the 2010 and 2014 inversac events lasted about 6 months and had a persistent chemical impact on the hydrosystem. It stayed perceptible on the quality of the water in certain compartments from 20 to 42 months after the occasional inversac intrusions ceased.

Even though the geochemical conditions within the hydrosystem were not monitored during the 2014 inversac event, the 2018 data are similar to those for 2012, suggesting that the hydrosystem did not reach its geochemical reference conditions and was still under a state of influence by the latest inversac event.

Geochemical analysis indicates that the 2010 inversac had the greatest impact on waters from the F6 well and the Cauvy spring, thus confirming the existence of a preferential groundwater flowpath between the Vise spring and those points.

The physico-chemical disturbances resulting from inversac event are not observed at sampling points CGE Tennis, P4 La Balme, and Issanka, located in the upgradient area of the Balaruc peninsula. The geochemical impact is, therefore, restricted to within a $1 \mathrm{~km}$ radius from the Vise spring (Fig. 10).

This slow geochemical recovery is best explained by the characteristic internal heterogeneity of the karst aquifer, which is typically described in terms of a triple porosity model comprising (i) matrix or primary porosity, (ii) fracture porosity, and (iii) conduit porosity (Palmer et al., 1999; Martin and Screaton, 2001). Influx of inversac water into the 


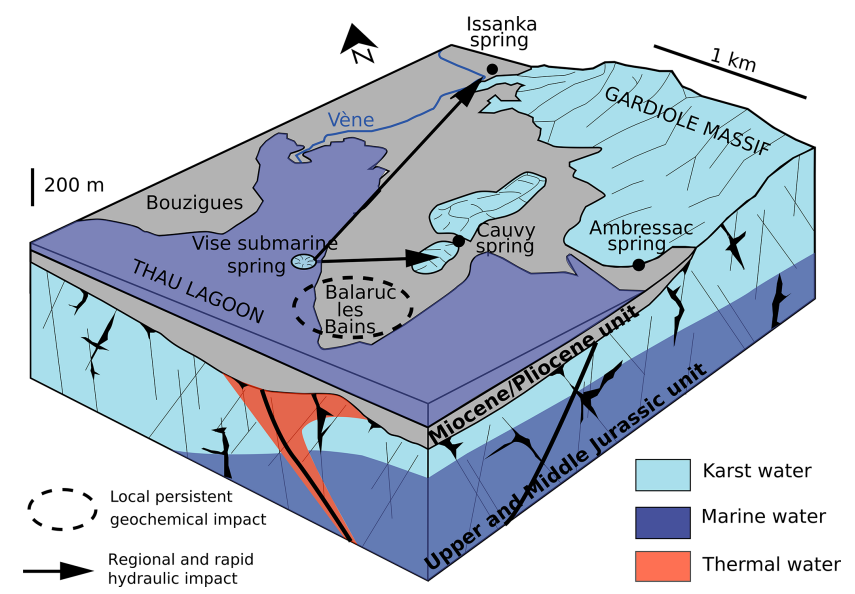

Figure 10. Block diagram of the study area showing the spatial extent of the hydraulic and geochemical impacts.

matrix porosity of the karst aquifer, its storage, and then prolonged time of removal and return to fracture and conduit flow explain the persistent fingerprint of the saltwater intrusions in the Balaruc peninsula.

Wells F8 and F10 in the southern part of the Balaruc peninsula were not affected by the inversac events. This part of the hydrosystem corresponds to a deeper compartment in the karst system, where the top of the Jurassic aquifer is $136 \mathrm{~m}$ deep in the F8 well and $195 \mathrm{~m}$ deep in the F10 well, which appears to be less hydraulically connected to the rest of the peninsula. Previous studies postulated that an indirect impact of an inversac event might occur (Ladouche et al., 2012). However, the increasing mineralization of F8 waters over time from $20 \mathrm{mS} \mathrm{cm}^{-1}$ in 1996 to $26.5 \mathrm{mS} \mathrm{cm}^{-1}$ in 2018 (Fig. S1 in the Supplement) suggests that waters from this well are not influenced by the occasional saltwater intrusions into the hydrosystem. This distinct evolution cannot be explained by pumping withdrawals as well withdrawal rates in the F8 thermal well were steady over the period of inversac monitoring. However, a decrease in the recharge rate from the karst system could result in an increase in the proportion of the thermal or marine end-member contributions. Recent monitoring of springs (Ambressac and S12) will address this question in the Dem'Eaux Thau project.

A comprehensive review of historical inversac events undertaken as part of this study showed that there is a hydraulic connection between the Villeveyrac Basin and the Balaruc peninsula. The relationship between these two regions is clearly demonstrated as dewatering of a bauxite mine in the Cambelliès area (Fig. 1) triggered the 1967 inversac event.

\subsection{Implications on groundwater management}

Results presented here illustrate the fragile equilibrium that exists between different groundwater bodies in the Thau hydrosystem. During low-flow conditions, any modification of the exploitation regime of the system can cause an inversac event and cause deleterious long-term consequences.

Historically, the 1967 and 2010 inversac events led to the complete cessation of withdrawal from the Cauvy spring, followed by its subsequent abandonment because the quality of this major drinking water supply was strongly impacted by the inversac events.

The Issanka spring is another major source of drinking water in the area for a population of 40000 . This study recognized the conditions needed for the hydraulic impact of an inversac event to reach the Issanka well field. Such new understanding can support water management operations by facilitating the prediction of the arrival of an inversac disturbance, using the criteria highlighted in Sect. 6.1.1.

While the southern compartment of the hydrosystem has not been impacted by inversac events, the gradual increase in mineralization observed for the F8 thermal well has the potential to affect its quality over time. In order to sustain the water quality of this thermal well, further studies should investigate the specific dynamics of this karstic compartment and the underlying mechanism explaining this observation. More specifically, the hydraulic connection between this deep compartment with the Sète thermal system south of the study area should be investigated.

Finally, unlike classical saline intrusion, the inversac events mobilize sediments loaded with organic matter during saltwater intrusions from the Vise spring. This intrusion of sediments may have an additional impact on the water quality within the karstic hydrosystem as suggested by B-isotopic signatures. Future studies could explore the fate and transport of the organic matter in the karst system.

\section{Conclusion}

This study investigated the impact of occasional saltwater intrusions (inversac in French) into the karst hydrosystem of the Balaruc peninsula and provides an improved understanding of the hydrodynamics and recovery of the aquifer from saltwater intrusions. Differences were observed between the hydraulic and geochemical responses, both spatially and temporally. The karst, thermal, and marine water bodies within different compartments of the karst system coexist within a very delicate equilibrium that is disturbed by the rapid intrusion of lagoon waters during inversac events. While the hydraulic impact of such saltwater intrusions is immediate and manifest over a distance of some $5 \mathrm{~km}$ within the hydrosystem, the geochemical impact focused within a $1 \mathrm{~km}$ radius around the Vise spring but was temporally persistent. Geochemical tracers showed that the hydrosystem did not reach its pre-inversac reference state 20 and 40 months after the occurrence of inversac of 6-month duration. The slow geochemical recovery of the Balaruc peninsula karst system reflects the triple-porosity character of the karst aquifer. Additionally, preliminary results suggested that the modification 
of the groundwater chemistry is initiated by an interaction process with clay sediments and organic matter during the saltwater intrusion event and possibly during the subsequent transfer of seawater to the karst aquifer through the Miocene formation. This study demonstrates the potential to couple physico-chemical, hydrogeological, and isotopic data to understand the complex inversac phenomenon and recognize preferential flowpaths during such events.

The results of this study support groundwater management across the Balaruc peninsula. The triggering factors of the saltwater intrusions were highlighted as well as the conditions needed for the saltwater intrusion to hydraulically impact the upgradient area, which is a major source of drinking water supply. While the water quality of some of the wells across the Balaruc peninsula are strongly impacted by the inversac and retain a geochemical signature of the event, the thermal wells located in the southern portion of the hydrosystem are not affected by inversac events, suggesting hydraulic isolation from the rest of the Balaruc peninsula.

Data availability. The geochemical and isotopic data are accessible at https://doi.org/10.5281/zenodo.3893897 (Pétré et al., 2020).

Supplement. The supplement related to this article is available online at: https://doi.org/10.5194/hess-24-5655-2020-supplement.

Author contributions. BL, JLS, and CL designed the study and data collection plan. MAP, JLS, and BL conducted the fieldwork, collected the hydrogeological and geochemical data, and performed the data analysis. MAP prepared the paper with contributions from $\mathrm{RH}$ and JLS. All the authors reviewed and edited the manuscript.

Competing interests. The authors declare that they have no conflict of interest.

Acknowledgements. The authors are thankful to the municipalities of Balaruc-les-Bains and Pézenas for continuous support during the 2018 fieldwork. Thanks are due to Franck Bujaldon (city of Pézenas), Ludovic Sarrou (thermal spa, Balaruc-les-Bains), Nathalie Masscheleyn (Balaruc-les-Bains municipality), David Mimard (Suez) and Vincent Durand (Antéa) for granting access to the thermal boreholes, karst springs, and piezometers. We are thankful to Jean-Gilbert Muller from President Electronics for providing access to the Ambressac spring. Gilles Lorente and Kevin Buttaro (Syndicat Mixte du Bassin de Thau) are thanked for their technical support during the March 2018 field campaign. We also acknowledge Nicolas Patris (HydroSciences Montpellier) for his help and useful discussion on stable isotopes. Remi Freydier (HydroSciences Montpellier) and graduate student Hikma Kassime are also thanked for their valuable contribution to the B-isotopic analyses. We thank Russell Harmon (North Carolina State University) for a thorough review of an earlier version of the manuscript.
Financial support. This research has been supported by the FEDER-CPER (Agence de l'Eau, Balaruc-les-Bains, SMBT, and BRGM) through the Dem'Eaux Thau project.

Review statement. This paper was edited by Philippe Ackerer and reviewed by Ekkehard Holzbecher and one anonymous referee.

\section{References}

Aggarwal, J. K. and Palmer, M. R.: Boron isotope analysis. A review, Analyst, 120, 1301-1307, 1995.

Aggarwal, J. K., Mezger, K., Pernicka, E., and Meixner, A.: The effect of instrumental mass bias on $\delta^{11} \mathrm{~B}$ measurements: a comparison between thermal ionisation mass spectrometry and multiplecollector ICP-MS, Int. J. Mass Spectrom., 232, 259-263, 2004.

Albéric, P.: River backflooding into a karst resurgence (Loiret, France), J. Hydrol., 286, 194-202, 2004.

Aquilina, L., Deluchat, V., Brach, M., Bakalowicz, M., Le Strat, P., and Giraud, F.: Etude géochimique des eaux souterraines autour du bassin de Thau, 15 fig., 4 tabl., 2 annexes, Rap. BRGM R39530, BRGM, France, p. 58, 1997.

Aquilina, L., Ladouche, B., Dörfliger, N., Seidel, J. L., Bakalowicz, M., Dupuy, C., and Le Strat, P.: Origin, evolution and residence time of saline thermal fluids (Balaruc springs, southern France): implications for fluid transfer across the continental shelf, Chem. Geol., 192, 1-21, 2002.

Aquilina, L., Ladouche, B., Doerfliger, N., and Bakalowicz, M.: Deep water circulation, residence time, and chemistry in a karst complex, Groundwater, 41, 790-805, 2003.

Arfib, B. and Gilli, E.: Karst côtier et sources sous-marines fonctionnement et exploitation, in: Grottes et karsts de France, Karstologia Mémoires 19, 978-2-9504222-5-5, edited by: Audra, P., Association Française de Karstologie, 128-129, 2010.

Arthaud, F. and Laurent, P.: Contraintes, déformation et déplacement dans l'avant-pays Nord-pyrénéen du Languedoc méditerranéen, Geodinam. Ac., 8, 142-157, https://doi.org/10.1080/09853111.1995.11105386, 1995.

Arthaud, F. and Seguret, M.: Les structures pyreneennes du Languedoc et du Golfe du Lion (Sud de la France), Bulletin de la Sociéte Géologique de France, S7-XXIII, 51-63, https://doi.org/10.2113/gssgfbull.S7-XXIII.1.51, 1981.

Arthaud, F., Mégard, F., and Séguret, M.: Cadre tectonique de quelques bassins sédimentaires, Bulletin du Centre de Recherche, d'Exploration et de Production, Elf-Aquitaine, 1, 147-188, 1977.

Bakalowicz, M.: Karst at depth below the sea level around the Mediterranean due to the Messinian crisis of salinity. Hydrogeological consequences and issues, Geol. Belg., 17, 96-101, 2014.

Baudrimont, A. F. and Dubois, P.: Un bassin mésogéen du domaine péri-alpin:le Sud-Est de la France, Bulletin Centre Recherche Exploration Production Elf-Aquitaine, 1, 262-308, 1977.

Benedicto, A., Labaume, P., Séguret, M., and Séranne, M.: Low-angle crustal ramp and basin geometry in the Gulf of Lion passive margin: Oligocene-aquitanian Vistrenque graben, SE France, Tectonics, 15, 1192-1212, https://doi.org/10.1029/96TC01097, 1996. 
Bonnet, A. and Paloc, H.: Les eaux des calcaires Jurassiques du bassin de Montbazin-Gigean et de ses bordures (pli de Montpellier et massif de la Gardiole Hérault), BRGM 69 SGL 207 LRO, BRGM, Orléans, France, 1969.

Choukroune, P. and Mattauer, M.: Tectonique des plaques et Pyrénées: sur le fonctionnement de la faille transformante nordpyrénéenne; comparaison avec des modèles actuels, Bulletin de la Societe Geologique de France, 7, 689-700, 1978.

Choukroune, P., Seguret, M., and Galdeano, A.: Caracteristiques et evolution structurale des Pyrenees; un modele de relations entre zone orogenique et mouvement des plaques, Bulletin de la Societe Geologique de France, S7-XV, 600-611, https://doi.org/10.2113/gssgfbull.S7-XV.5-6.600, 1973.

Chu, Y., Tournoud, M. G., Salles, C., Got, P., Perrin, J.-L., Rodier, C., Caro, A., and Troussellier, M.: Spatial and temporal dynamics of bacterial contamination in South France coastal rivers: focus on in-stream processes during low flows and floods, Hydrol. Process., 28, 3300-3313, 2014.

Clauzon, G.: Le canyon messinien du Rhône; une preuve décisive du "desiccated deep-basin model" (Hsue, Cita and Ryan, 1973), Bulletin de la Sociéte Géologique de France, S7-XXIV, 597-610, https://doi.org/10.2113/gssgfbull.S7-XXIV.3.597, 1982.

Combes, J.-P.: Typologie, cadre géodynamique des bauxites téthysiennes, Geodinam. Ac., 4, 91-109, 1990.

Debrand-Passard, S.: Synthèse géologique du Sud-Est de la France - Stratigraphie et paléogéographie, vol. 125-126, Mémoire BRGM, Orléans, France, 1984.

Doerfliger, N., Ladouche, B., Bakalowicz, M., Pinault, J.-L., and Chemin, P.: Étude du pourtour est de l'étang de Thau, phase II. Synthèse générale, Volume 4, 34 fig., 3 tabl., 2 photos, BRGM/RP-50789-FR, BRGM, France, p. 71, 2001.

Drogue, C. and Bidaux, P.: Simultaneous outflow of fresh water and inflow of sea water in a coastal spring, Nature, 322, 361-363, https://doi.org/10.1038/322361a0, 1986.

Faure, G.: Principles of isotope geology, 2nd Edn., Wiley, NewYork, p. 588, 1986.

Fleury, P.: Sources sous-marines et aquifères karstiques côtiers méditerranéens: Fonctionnement et caractérisation, Université Pierre et Marie Curie, Paris VI, available at: https: //tel.archives-ouvertes.fr/tel-00789234/document (last access: 14 June 2020), 2005.

Fleury, P., Bakalowicz, M., and de Marsily, G.: Submarine springs and coastal karst aquifers: a review, J. Hydrol., 339, 79-92, 2007.

Gèse, B.: Les mésaventures des sources de l'Estavelle et de l'Inversac en Languedoc méditerranéen, Int. J. Speleol., 16, 101109,1987

Gill, L. W., Babechuk, M. G., Kamber, B. S., McCormack, T., and Murphy, C.: Use of trace and rare earth elements to quantify autogenic and allogenic inputs within a lowland karst network, Appl. Geochem., 90, 101-114, https://doi.org/10.1016/j.apgeochem.2018.01.001, 2018.

Guerrot, C., Millot, R., Robert, M., and Négrel, P.: Accurate and High-Precision Determination of Boron Isotopic Ratios at Low Concentration by MC-ICP-MS (Neptune), Geostand. Geoanalyt. Res., 35, 275-284, https://doi.org/10.1111/j.1751908X.2010.00073.x, 2011.

Han, D., Post, V. E., and Song, X.: Groundwater salinization processes and reversibility of seawater intrusion in coastal carbonate aquifers, J. Hydrol., 531, 1067-1080, 2015.
Hershey, J. P., Fernandez, M., Milne, P. J., and Millero, F. J.: The ionization of boric acid in $\mathrm{NaCl}, \mathrm{NaCaCl}$ and $\mathrm{NaMgCl}$ solutions at $25^{\circ} \mathrm{C}$, Geochem. Cosmochim. Ac., 50, 143-148, https://doi.org/10.1016/0016-7037(86)90059-1, 1986.

Hsu, K. J., Cita, M. B., and Ryan, W. B. F.: The origin of the Mediterranean evaporites, in: Initial reports of the deep sea drilling project, 13, edited by: Ryan, W. B. F. and Hsu, K. J., 1203-1231, available at: http://deepseadrilling.org/13/volume/ dsdp13pt2_43.pdf (last access: 15 June 2020), 1973.

Johannesson, K. H., Stetzenbach, K. J., and Hodge, V. F.: Rare earth elements as geochemical tracers of regional groundwater mixing, Geochim. Cosmochim. Ac., 61, 3605-3618, https://doi.org/10.1016/S0016-7037(97)00177-4, 1997.

Joigneaux, E., Albéric, P., Pauwels, H., Pagé, C., Terray, L., and Bruand, A.: Impact of climate change on groundwater point discharge: backflooding of karstic springs (Loiret, France), Hydrol. Earth Syst. Sci., 15, 2459-2470, https://doi.org/10.5194/hess-152459-2011, 2011.

Kakihana, H., Kotaka, M., Satoh, S., Nomura, M., and Okamoto, M.: Fundamental studies on the ion-exchange separation of boron isotopes, Bull. Chem. Soc. Jpn., 50, 158-163, 1977.

Ladouche, B. and Lamotte, C.: Inversac de la source sous-marine de la Vise en 2014: Recueil et analyse des données disponibles, 56 ill., Rapport final BRGM/RP-64812-FR, BRGM, France, p. 82, 2015.

Ladouche, B., Aquilina, L., Cubizoles, J., and Négrel, P.: Rainfall chemistry in the south of France (Hérault, 1996-1997), in Mineralogical Magazine, in: 8th Annual VM Goldschmidt Conference, 30, 842-843, 1998.

Ladouche, B., Doerfliger, N., Bakalowicz, M., and avec la collaboration de Cubizolles, J.: Étude du pourtour est de l'étang de Thau. Phase II. Caractérisation hydrochimique des réservoirs souterrains karstiques et thermaux, Volume 3, 20 fig., 5 tabl., 5 ann., BRGM/RP-50788-FR, BRGM, France, p. 79, 2001.

Ladouche, B., Millot, R., Guerrot, C., and Lamotte, C.: Caractérisation géochimique des eaux de l'hydrosystéme de la presqu'île de Balaruc-Les-Bains lors d'un épisode d'inversac, BRGM/RP 59922-FR, 4 ann., 24 ill., BRGM, France, 93 pp., 2011.

Ladouche, B., Millot, R., Guerrot, C., and Lamotte, C.: Caractérisation géochimique de l'aquifère hydrothermal de Balarucles-Bains lors d'un épisode d'inversac, in Dix-huitièmes journées techniques du Comité Français d'Hydrogéologie de l'Association Internationale des Hydrogéologues, Ressources et gestion des aquifères littoraux. Cassis 2012, Cassis, France, 141-149, available at: https://hal-brgm.archives-ouvertes.fr/ hal-00680642 (last access: 16 August 2018), 2012.

Ladouche, B., Lamotte, C., Hemelsdael, R., Pétré, M.-A., Dewandel, B., Leonardi, V., Seidel, J.-L., and Séranne, M.: Dem'Eaux Thau - Synthèse et valorisation préliminaire des données sur l'hydrosystème de Thau (34), 133 fig., 6 tab., 6 ann., Rapport final, BRGM/RP-68483-FR, BRGM, France, p. 313, 2019.

La Jeunesse, I., Cirelli, C., Sellami, H., Aubin, D., Deidda, R., and Baghdadi, N.: Is the governance of the Thau coastal lagoon ready to face climate change impacts?, Ocean Coast. Manage., 118, 234-246, 2015.

Maerten, L. and Séranne, M.: Extensional tectonics of the OligoMiocene Herault Basin (S France), Gulf of Lion margin, Bulletin de la Sociéte Géologique de France, 166, 739-749, 1995. 
Marchand, E., Séranne, M., Bruguier, O., and Vinches, M.: LA-ICP-MS dating of detrital zircon grains from the Cretaceous allochthonous bauxites of Languedoc (south of France): Provenance and geodynamic consequences, Basin Research, https://doi.org/10.1111/bre.12465, in press, 2020.

Martin, J. B. and Screaton, E. J.: Exchange of matrix and conduit water with examples from the Floridan aquifer, US Geological Survey Karst Interest Group Proceedings, St. Petersburg, Florida, 38-44, 2001.

Palmer, A., Palmer, M., and Sasowsky, I.: Karst modeling, Karst Waters Institute, Charles Town, West Virginia, 1999.

Pétré, M.-A., Ladouche, B., Seidel, J.-L., Hemelsdaël, R., de Montety, V., Batiot-Guilhe, C., and Lamotte, C.: Hydraulic and geochemical impact of occasional saltwater intrusions through a submarine spring in a karst and thermal aquifer (Balaruc peninsula near Montpellier, France), Zenodo, https://doi.org/10.5281/zenodo.3893897, 2020.

Pinault, J.-L., Dörfliger, N., Ladouche, B., and Bakalowicz, M.: Characterizing a coastal karst aquifer using an inverse modeling approach: The saline springs of Thau, southern France, Water Resour. Res., 40, W08501, https://doi.org/10.1029/2003WR002553, 2004.

Ryan, W. B. F.: Quantitative evaluation of the depth of the western Mediterranean before, during and after the Late Miocene salinity crisis, Sedimentology, 23, 791-813, https://doi.org/10.1111/j.1365-3091.1976.tb00109.x, 1976.
Séranne, M.: The Gulf of Lion continental margin (NW Mediterranean) revisited by IBS: an overview, Geol. Soc. Lond. Spec. Publ., 156, 15-36, https://doi.org/10.1144/gsl.sp.1999.156.01.03, 1999.

Stieglitz, T. C., van Beek, P., Souhaut, M., and Cook, P. G.: Karstic groundwater discharge and seawater recirculation through sediments in shallow coastal Mediterranean lagoons, determined from water, salt and radon budgets, Mar. Chem., 156, 73-84, 2013.

Taylor, S. and McLennan, S.: The continental crust: its composition and evolution, Blackwell Scientific Publications, Oxford, 1985.

Thaler, L.: Premiers résultats d'une recherche systématique des dents de rongeurs, par lavage de marnes de l'Oligocène, en Bas-Languedoc, Comptes Rendus Sommaires de la Société Géologique de France, 10, 315-315, 1962.

Tweed, S. O., Weaver, T. R., Cartwright, I., and Schaefer, B.: Behavior of rare earth elements in groundwater during flow and mixing in fractured rock aquifers: An example from the Dandenong Ranges, southeast Australia, Chem. Geol., 234, 291-307, https://doi.org/10.1016/j.chemgeo.2006.05.006, 2006.

Zhan, Y., Guo, H., and Xing, L.: Characteristics of Rare Earth Elements in Groundwaters along the Flow Path in the North China Plain, Proced. Earth Planet. Sci., 7, 940-943, https://doi.org/10.1016/j.proeps.2013.03.173, 2013. 